\title{
Structural Conservation and Adaptation of the Bacterial Flagella Motor
}

\author{
Brittany L. Carroll $1,2 \oplus$ and Jun Liu ${ }^{1,2, *}$ \\ 1 Department of Microbial Pathogenesis, Yale School of Medicine, New Haven, CT 06536, USA; \\ Brittany.Carroll@yale.edu \\ 2 Microbial Sciences Institute, Yale University, West Haven, CT 06516, USA \\ * Correspondence: jliu@yale.edu
}

Received: 5 October 2020; Accepted: 27 October 2020; Published: 29 October 2020 updates

\begin{abstract}
Many bacteria require flagella for the ability to move, survive, and cause infection. The flagellum is a complex nanomachine that has evolved to increase the fitness of each bacterium to diverse environments. Over several decades, molecular, biochemical, and structural insights into the flagella have led to a comprehensive understanding of the structure and function of this fascinating nanomachine. Notably, X-ray crystallography, cryo-electron microscopy (cryo-EM), and cryo-electron tomography (cryo-ET) have elucidated the flagella and their components to unprecedented resolution, gleaning insights into their structural conservation and adaptation. In this review, we focus on recent structural studies that have led to a mechanistic understanding of flagellar assembly, function, and evolution.
\end{abstract}

Keywords: bacterial flagellum; cryo-electron tomography; cryo-electron microscopy; molecular motor; structure and function; torque generation; evolution

\section{Introduction}

The flagellum, a complex nanomachine, propels bacteria through media and along surfaces, using an ion gradient across the cytoplasmic membrane (for review [1]). All flagella share basic structural elements, including the filament, hook, and motor (Figure 1A). The filament acts as the propeller guiding the bacterium through space, while the hook acts as a joint transmitting energy from the motor to the filament [2-6]. The motor, or basal body is homologous to the non-flagellar type III secretion system (T3SS) (for review [7]). The filament can present either externally (Figure 1B,C) or periplasmically (Figure 1D). External flagella extend through the outer membrane into the media surrounding the bacterium and can further be categorized as lateral, peritrichous, and polar [8], while periplasmic flagella reside within the periplasmic space and are essential for spirochete motility [9].

The flagella of Salmonella enterica (henceforth called Salmonella) and Escherichia coli possess the best-studied motors, consisting of the membrane/supramembrane (MS) ring, cytoplasmic (C) ring, peptidoglycan $(\mathrm{P})$ ring, lipopolysaccharide $(\mathrm{L})$ ring, rod, stator, and export apparatus. The MS ring (FliF) acts a base upon which the motor sits, and the $\mathrm{C}$ ring (FliG, FliM, and FliN) controls the rotation sense [10-16]. The stator generates torque through ion gradients, mainly $\mathrm{H}^{+}$(MotA and MotB) and sometimes $\mathrm{Na}^{+}$(PomA and PomB), which drives the rotation of the $\mathrm{C}$ ring $[14,15,17-19]$. The $\operatorname{rod}(\mathrm{FlgB}, \mathrm{FlgC}$, and $\mathrm{FlgF}$, and $\mathrm{FlgG}$ ) acts as a drive shaft, connecting the MS ring to the hook [20-22], and the $\mathrm{L}(\mathrm{FlgH})$ and $\mathrm{P}(\mathrm{FlgI})$ rings act as the bushings, providing support to the rotating rod [23]. The export gate complex, (FlhA, FlhB, FliP, FliQ, and FliR) and ATPase complex (FliH, FliI, and FliJ) [24-26] are responsible for the temporal and spatial assembly, ensuring that a functional flagellum is built [27]. Advances in structural biology techniques, specifically cryo-electron microscopy (cryo-EM) and cryo-electron tomography (cryo-ET), have led to the investigation of flagella from many 
other species, resulting in the identification of conserved and specifically adapted structural features. Cryo-ET uniquely allows for the visualization of flagellar structures in situ, without the necessity of isolation and purification of the complexes. In this review, we summarize the plethora of structural work that has widened our view of the assembly, adaptation, and evolution of bacterial flagella.

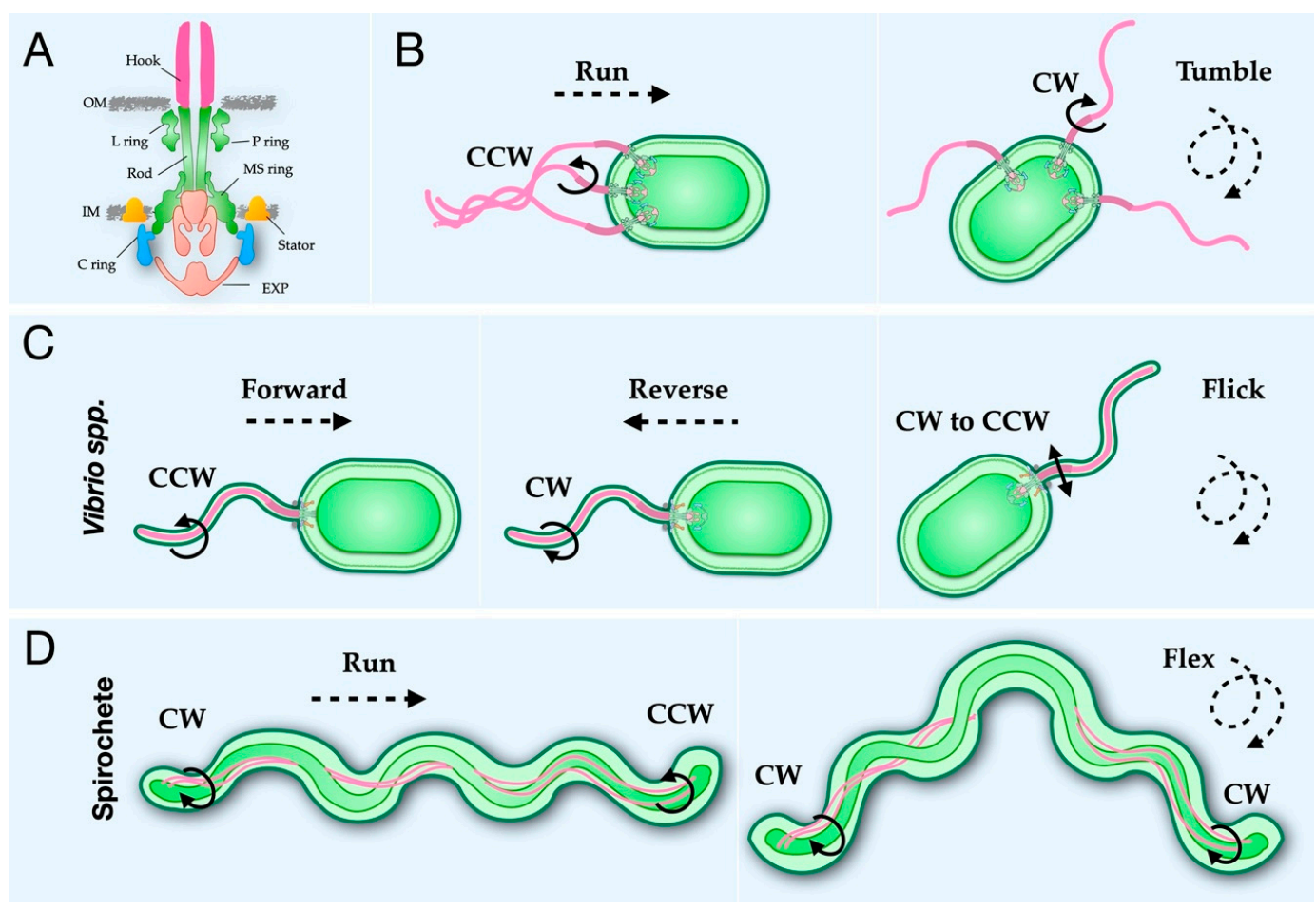

Figure 1. Bacterial flagella control distinct motility. The flagellar motor is a complex nanomachine that drives filament rotation. (A) Cartoon model of the flagellar motor. (B) In the two-step model used by many species, such as E. coli and Salmonella, the cell body is propelled forward, or runs, during counterclockwise (looking from the motor to the filament, CCW) rotation, and the filaments form an organized bundle. To change direction, the cell tumbles by rotating the filament in the clockwise (CW) direction, unwinding the bundle. (C) Vibrio spp. use a three-step method, with CCW rotation moving the cell body forward, CW rotation moving the cell body in reverse, and a flicking motion when CW-to-CCW randomly change direction. (D) Spirochetes, with periplasmic flagella at both poles, require a unique two-step method. During the run, the flagella rotate CCW and CW at opposite poles, such that one pole "pulls" while the other "pushes". Both poles rotate in the CW direction while the cell tumbles to change direction.

\section{The Bacterial Flagellar Structure}

Structural studies have illustrated how the flagellum is assembled and the unique features that have evolved in different species. X-ray crystallography is particularly powerful in unveiling many atomic structures of individual flagellar proteins as well as small subcomplexes (Table 1). These atomic models provide invaluable insight into the individual proteins and protein-protein interactions involved in flagellar assembly and aid in designing functional studies. Recently, cryo-EM has been increasingly utilized to provide both medium- and high-resolution structures of many flagellar subcomplexes, elucidating variable symmetry and complexity of the motor (Table 2). However, the flagellum as an intact organelle is far too complex and flexible for X-ray crystallography and cryo-EM. Cryo-ET coupled with subtomogram averaging [28] has the unique capacity to reveal the entirety of bacterial flagella in multiple species, depicting the relative arrangement of the rings and other protein complexes of the flagella in situ (Table 3). In this section, we review the structural information that not only is conserved but also provides a basis for understanding the functions. 
Table 1. Crystal structures of flagellar proteins. A list of the flagellar protein structures deposited in the PDB.

\begin{tabular}{|c|c|c|c|}
\hline Protein(s) & Species & PDB ID & Refs \\
\hline \multicolumn{4}{|c|}{ Axial } \\
\hline \multirow{5}{*}{$\begin{array}{l}\text { Flagellin } \\
\text { FliC }\end{array}$} & Bacillus cereus & $5 Z 7 Q$ & [29] \\
\hline & Salmonella typhimurium & $1 \mathrm{IO} 1$ & [30] \\
\hline & Sphingaomonas sp & 2ZBI, 3K8V, 3K8W & [31] \\
\hline & Burkholderia psuedomallei & $4 \mathrm{CFI}$ & [32] \\
\hline & Pseudomonas aeruginosa & $4 \mathrm{~N} \times 9$ & [33] \\
\hline \multirow{3}{*}{ FliS } & Aquifex aeolicus & 1ORY, 1ORJ & [34] \\
\hline & Bacillus cereus & 5XEF & [35] \\
\hline & Helicobacter pylori & 3IQC & [36] \\
\hline \multirow{2}{*}{ FliT } & Salmonella typhimurium & 5GNA & \\
\hline & Yersinia enterocolitica & 3NKZ & \\
\hline FljB & Salmonella typhimurium & 6RGV & [37] \\
\hline FcpA & Leptospira biflexa & 6NQY & [38] \\
\hline FcpB & Leptospira interrogans & $6 \mathrm{NQZ}$ & [38] \\
\hline Flagellin-FliS & Bacillus subtilis & 5MAW, 6GOW & [39] \\
\hline FliC-FliS fusion & Aquifex aeolicus & 4IWB & [40] \\
\hline \multirow{2}{*}{ FlgD } & Helicobacter pylori & $4 Z Z F, 4 Z Z K, 5 K 5 Y$ & {$[41,42]$} \\
\hline & Salmonella typhimurium & 6IEE, 6IEF & \\
\hline \multirow{5}{*}{ FlgE } & Campylobacter jejuni & 5AZ4 & [43] \\
\hline & Caulobacter crescentus & $5 \mathrm{AY} 6$ & [43] \\
\hline & Helicobacter pylori & $5 \mathrm{NPY}$ & [44] \\
\hline & Salmonella typhimurium & $1 W L G$ & [45] \\
\hline & Treponema denticola & 6NDT, 6NDW, 6NDV, 6NDX & [46] \\
\hline \multirow[t]{2}{*}{ FlgK } & Campylobacter jejuni & $5 \mathrm{XBJ}$ & [47] \\
\hline & Bacillus cereus & $5 Z \mathrm{IIY}$ & [48] \\
\hline \multirow[t]{2}{*}{ FlgL } & Xanthomonas campestris & 5ZIZ, 5ZJ0 & [48] \\
\hline & Legionella pneumophila & 5YTI & \\
\hline \multirow{2}{*}{ FliD (HAP2) } & Pseudomonas aeruginosa & 5FHY & [49] \\
\hline & Helicobacter pylori & $6 \mathrm{IWY}$ & {$[50]$} \\
\hline FlgG & Salmonella typhimurium & $6 \mathrm{JF} 2$ & [51] \\
\hline FlgJ & Salmonella typhimurium & 5DN4, 5DN5 & {$[52]$} \\
\hline \multicolumn{4}{|c|}{ Basal Body } \\
\hline FlgA & Salmonella typhimurium & 3VKI, 3VJP, 3TEE & [53] \\
\hline FliF-FliG & Helicobater pylori & $5 \mathrm{WUJ}$ & [54] \\
\hline $\mathrm{FliF}_{\mathrm{c}}-\mathrm{FliG}_{\mathrm{N}}$ & Thermotaoga maritima & 5TDY & {$[55]$} \\
\hline \multirow{4}{*}{ FliG } & Aquifex aeolicus & $3 \mathrm{HJL}$ & [56] \\
\hline & Helicobacter Pylori & 3USY, 3USW & [57] \\
\hline & Thermotoga maritima & 1LKV, 1QC7, 3AJC & {$[58-60]$} \\
\hline & Helicobacter pylori & 4GC8 & {$[61]$} \\
\hline \multirow[t]{2}{*}{ FliM } & Thermotoga maritima & $2 \mathrm{HP7}$ & [62] \\
\hline & Helicobacter pylori & 5XRW & [63] \\
\hline FliN & Thermotaoga maritima & 1YAB, 1O6A & {$[64]$} \\
\hline FliY & Thermotoga maritima & $4 \mathrm{HYN}$ & [65] \\
\hline \multirow{2}{*}{ FliG-FliM } & Helicobacter pylori & 4FQ0 & [61] \\
\hline & Thermotaoga maritima & $3 \mathrm{SOH}, 4 \mathrm{FHR}, 4 \mathrm{QRM}$ & [66-68] \\
\hline FliM-FliN & Salmonella typhimurium & $4 X Y B$ & [69] \\
\hline FliM-FliN-FliH & Salmonella typhimurium & $4 X Y C$ & [70] \\
\hline FliM-SpeE & Helicobacter pylori & $5 \times 0 Z$ & [71] \\
\hline \multirow[t]{2}{*}{ CheY } & Escherichia coli & $\begin{array}{l}\text { 1U8T, 1ZDM, 2B1J, 2ID7, 2ID9, } \\
\text { 2IDM, 6TG7 }\end{array}$ & {$[72,73][74]$} \\
\hline & Thermotoga maritima & $4 \mathrm{IGA}$ & [75] \\
\hline CheY3 & Vibrio cholerae & 3TO5, 4H60, 4HNQ, 4JP1, 4LX8 & [76] \\
\hline CheY4 & Vibrio cholerae & $4 \mathrm{HNR}, 4 \mathrm{HNS}$ & [76] \\
\hline CheY-FliM & Escherichia coli & $1 \mathrm{~F} 4 \mathrm{~V}$ & {$[72]$} \\
\hline FlhG & Geobacillus thermodenitrificans & 4RZ2, 4RZ3 & [77] \\
\hline MotB & Salmonella typhimurium & $5 Y 3 Z, 5 Y 40,2 Z V Y, 2 Z V Z, 2 Z O V$ & {$[78,79]$} \\
\hline PomB $_{c}$ & Vibrio alginolyticus & $3 \mathrm{WPW}, 3 \mathrm{WPX}$ & [80] \\
\hline MotY & Vibrio alginolyticus & $2 \mathrm{ZF} 8$ & [81] \\
\hline FliL & Vibrio alginolyticus & 6AHQ, 6AHP & [82] \\
\hline FlgT & Vibrio alginolyticus & $3 \mathrm{~W} 1 \mathrm{E}$ & [83] \\
\hline
\end{tabular}


Table 1. Cont.

\begin{tabular}{|c|c|c|c|}
\hline Protein(s) & Species & PDB ID & Refs \\
\hline \multicolumn{4}{|c|}{ Export Apparatus } \\
\hline & Bacillus subtilis & 3MIX & [84] \\
\hline FlhA & Salmonella typhimurium & 6CH1, 6AI0, 6AI1, 6AI2, 6AI3 & {$[85,86]$} \\
\hline $\begin{array}{l}\text { FlhA FliT-FliD } \\
\text { complex }\end{array}$ & Salmonella typhimurium & $6 \mathrm{CH} 2$ & [85] \\
\hline $\begin{array}{c}\text { FlhA FliS-FliC } \\
\text { complex }\end{array}$ & Salmonella typhimurium & $6 \mathrm{CH} 3$ & [85] \\
\hline & Aquifex aeolicus & 3B1S & [87] \\
\hline FIIB & Salmonella typhimurium & 3B0Z & [87] \\
\hline FlhF & Bacillus subtilis & $2 \mathrm{PX} 0,2 \mathrm{PX} 3$ & [88] \\
\hline FliI & Salmonella typhimurium & 2DPY & [89] \\
\hline FliJ & Salmonella typhimurium & 3AJW & [90] \\
\hline \multirow{2}{*}{ FlgN } & Pseudomonas aeruginosa & 2FUP & \\
\hline & Salmonella typhimurium & $5 \mathrm{~B} 3 \mathrm{D}$ & [91] \\
\hline FliH-FliI & Salmonella typhimurium & $5 \mathrm{~B} 0 \mathrm{O}$ & [92] \\
\hline
\end{tabular}

Table 2. Cryo-EM structures for flagellar subcomplexes. A list of the cryo-EM maps and models deposited in the EMDB and PDB.

\begin{tabular}{|c|c|c|c|c|}
\hline Protein(s) & Species & PDB ID & EMDB ID & Refs \\
\hline & & Axial & & \\
\hline \multirow{6}{*}{ Flagellin } & Campylobacter jejuni & & 5007 & [93] \\
\hline & Salmonella typhimurium & 1UCU, 3A5X & 1641 & {$[94,95]$} \\
\hline & Bacillus subtilis & $\begin{array}{c}\text { 5WJT, 5WJU, 5WJV, } \\
\text { 5WJW, 5WJX, } \\
\text { 5WJY, 5WJZ }\end{array}$ & $\begin{array}{c}8447,8848,8849,8850 \\
8851,8852,8853\end{array}$ & [96] \\
\hline & Pseudomonas aeruginosa & 5WK5, 5WK6 & 8855,8856 & [96] \\
\hline & Leptospira biflexa & 6PWB & 20504 & [38] \\
\hline & Salmonella typhimurium & 6JY0 & 9896 & [97] \\
\hline \multirow{4}{*}{ FlgE } & Kurthia spp. & 6T17 & 10362 & [98] \\
\hline & Helicobacter pylori & 5JXL & 8179 & [99] \\
\hline & Caulobacter crescentus & 2BGY & 1132 & [100] \\
\hline & Salmonella typhimurium & $\begin{array}{c}\text { 2BGZ, 3A69, 6JZT, } \\
\text { 6KFK, 6K3I }\end{array}$ & $1132,1647,9974,9909$ & $\begin{array}{c}{[100,101]} \\
{[51,102,103]}\end{array}$ \\
\hline & Salmonella enterica & $6 \mathrm{~K} 9 \mathrm{Q}$ & 9952 & [104] \\
\hline FliD (HAP2) & Escherichia coli & & 1873 & [105] \\
\hline \multirow[t]{2}{*}{ FlgG } & Salmonella typhimurium & $6 \mathrm{JZR}$ & 6683 & [51] \\
\hline & & Basal Body & & \\
\hline & Salmonella typhimurium & & 1887 & {$[106]$} \\
\hline FliF & Salmonella typhimurium & $\begin{array}{c}\text { 6SCN, 6SD1, 6SD2, } \\
\text { 6SD3, 6SD4, } \\
\text { 6SD5, 6TRE }\end{array}$ & $\begin{array}{c}10143,10145,10146, \\
10147,10148,10149, \\
10560,6715\end{array}$ & {$[107,108]$} \\
\hline FliF-FliG & Salmonella typhimurium & & 6716 & [108] \\
\hline \multirow[t]{2}{*}{ MotA } & Aquifex aeolicus & & 3417 & [109] \\
\hline & Campylobacter jejuni & 6YKM, 6YKP, 6YKR & $10828,10829,10830$ & [110] \\
\hline \multirow[t]{2}{*}{ MotA/B } & Clostridium sporogenes & 6YSF & 10895,10897 & [111] \\
\hline & Bacillus subtilis & 6YSL & 10899 & [111] \\
\hline PomA/PomB & Vibrio mimicus & & 10901 & [111] \\
\hline \multicolumn{5}{|c|}{ Export Apparatus } \\
\hline \multirow{3}{*}{ FliPQR } & Salmonella typhimurium & 6R69, 6F2D & 4733,4173 & [107] \\
\hline & Vibrio mimicus & 6S3S & 10096 & [112] \\
\hline & Pseudomonas savastanoi & $6 \mathrm{~S} 3 \mathrm{R}$ & 10095 & [112] \\
\hline FliPQR-FlhB & Vibrio mimicus & $6 \mathrm{~S} 3 \mathrm{~L}$ & 10093 & [112] \\
\hline SctRST & Salmonella typhimurium & 6R6B & 4734 & [107] \\
\hline
\end{tabular}


Table 3. In situ flagellar motors visualized by cryo-ET. A list containing the cryo-ET maps of flagellar motors deposited in the EMDB. Note that not all cryo-ET maps are deposited.

\begin{tabular}{|c|c|c|}
\hline Species & EMDB ID & Refs \\
\hline Acetonema longum & 5297 & [113] \\
\hline Arcobacter butzleri & 3910 & [114] \\
\hline Borrelia burgdorferi & $\begin{array}{c}0525,0534,0536,0537,0538,1644, \\
5298,5627,5628,5629,5630,5631, \\
5632,5633,6088,6089,6090,6091, \\
6092,6093,6094,6095,6096,6097, \\
6098,9123,21885,21884,21886\end{array}$ & {$[113,115-120]$} \\
\hline Bdellovibrio bacteriovorus & 3911 & [114] \\
\hline Campylbacter jejuni & $\begin{array}{c}3150,3157,3158,3159,3160,3161 \\
5300,10341,10342,10343,10345 \\
10454,10455,10456,10457\end{array}$ & {$[113,121,122]$} \\
\hline Caulobacter crescentus & $\begin{array}{c}5312,10943,10945,10949,10950 \\
10955,10956,10957\end{array}$ & {$[113,123]$} \\
\hline Escherichia coli & 5311 & [113] \\
\hline Helicobacter pylori & 8459 & [57] \\
\hline Heliobacter Hepaticus & 5299 & [113] \\
\hline Hylemonella gracilis & 5309 & [113] \\
\hline Hyphomonas neptunium & 5313 & [113] \\
\hline Legionella pneumophila & 0464 & [124] \\
\hline Leptospira biflexa & 20503,20504 & [38] \\
\hline Leptospira interrogans & $5912,5913,5914$ & [6] \\
\hline Plesiomonas shigelloides & 4569,10057 & [125] \\
\hline Pseudomonas aeruginosa & 0465 & [124] \\
\hline Salmonella enterica & $2520,2521,3154,3813,5310$ & {$[113,121,126]$} \\
\hline Shewanella oneidensis & 0467 & [124] \\
\hline Treponema primitia & 1235 & [127] \\
\hline Vibrio cholerae & 5308 & [113] \\
\hline Vibrio fischeri & $3155,3156,3162$ & [121] \\
\hline Vibrio alginolyticus & 21819,21837 & [128] \\
\hline Wolinella succinogenes & 3912 & [114] \\
\hline
\end{tabular}

\subsection{The Rod, Hook, and Filament Extend from the Cell Body}

The flagellar filament is comprised of 11 protofilaments, each with thousands of repeating units of flagellin (for review [129]). Although, variation of the filament is possible, such as in the case of Campylobacter jejuni with 7 protofilaments [93]. The flagellin protein (FliC) has four domains-D0, D1, D2, and D3 [30] — and the protofilaments can adopt both left- and right-handed helical rotations. The filament forms a left-handed supercoil when rotating CCW and a right-handed supercoil during CW rotation, together coined polymorphic switching [130-132]. The Namba group solved atomic models of locked right-handed and left-handed Salmonella filaments using cryo-EM, elucidating key interacting regions of the flagellin protein [94,95]. Recently, the Bacillus subtilis and Pseudomonas aeruginosa locked filaments were revealed by using cryo-EM as well [96]. Importantly, due to improved resolution, Wang et al. were able to predict point mutations involved in polymorphic switching, which will aid future work towards a better understanding of the filament rotation [96].

The hook, composed of 120 copies of FlgE forming 11 protofilaments, has the critical job of joining the filament to the basal body, requiring a balance of rigidity and flexibility to allow the transfer of energy without breaking [133]. FlgE has 4 domains: D0 forms the channel, D1 forms the middle body, D2 forms the exposed surface, and Dc loops back in towards D0 [103]. Advances in cryo-EM enable high-resolution views of the hook as a bended structure during flagellar rotation $[103,104]$ or the earlier structures that were limited to straight segments [45,94,99]. Different from the two-state model [134], these studies revealed 11 different subunit conformations, suggesting that each protofilament has unique interdomain interactions allowing for compression and extension as necessary during rotation. 
The super helical pitch of the hook is dependent upon the environment, with a helical pitch of $996 \AA$ at $\mathrm{pH} 3.5$ [103] and 1,290 $\AA$ at $\mathrm{pH} 8$ [104], indicating that the environment also plays a role in the supercoiled form.

The rod is the most proximal region of the axial structure and acts as the drive shaft. It can be divided into two regions: the proximal rod contains six monomers of $\mathrm{FlgB}, \mathrm{FlgC}$, and $\mathrm{FlgF}$ and nine monomers of FliE, and the distal rod contains 26 copies of FlgG [135-137]. Biochemical characterization of the rod proteins suggests that FliE associates with the MS ring $[25,137]$ and also with the proximal protein assembly of $\mathrm{FlgB}, \mathrm{FlgF}$, and FlgC [138]. A cryo-ET study looking at flagellar assembly in the spirochete Borrelia burgdorferi broke down the assembly of the proximal rod, distal rod, hook, and filament using various deletion mutants, confirming the previous cellular studies [119]. A recent crystal structure of the core fragment of FlgG from Salmonella docked into the cryo-EM maps of the distal rod [139] and hook [102] identified the importance of the L-stretch in stabilization of the rod-hook junction [51]. There was also striking similarity between FlgG and FlgE, highlighting the fluidity of the rod-hook junction evolution [51]. Importantly, the static structures of the rod, hook, and filament observed by X-ray and cryo-EM lack the payload stress that occurs during flagellar rotation; therefore, different forces acting on these structures during filament rotation may alter their configuration.

\subsection{The Periplasmic $P$ and L Rings Stabilize the Rod}

Analogous to the bushing, the $\mathrm{P}(\mathrm{FlgI})$ and $\mathrm{L}(\mathrm{FlgH})$ rings are located within the periplasmic space and encircle and stabilize the rod [23]. The L ring was thought to catalyze the removal of the rod cap protein, FlgJ [140]. Bioinformatic analysis suggests that the P and L rings are highly conserved yet evolved separately, rather than via horizontal gene transfer [141]. Visualization of the PL rings from a dozen diverse bacterial species further supports their conservation among phyla [141,142]. Recent cryo-ET studies have found that the $\mathrm{P}$ and $\mathrm{L}$ rings form the outer membrane structures when the flagellum is absent $[125,142,143]$. These novel structures, identified by different groups, have been called outer-membrane partial flagellar structures, flagellar outer membrane complexes (FOMCs), or PL subcomplexes [125,141-143]. These complexes were suggested to be relics from which flagella have detached or been sheared, as the rod appears to be required for the assembly of the subcomplexes. Furthermore, Zhu et al. did not observe FOMCs in a P. aeruginosa flgG mutant, suggesting that the distal rod is necessary for the formation of the FOMCs [143]. Interestingly, the sheathed flagellum (discussed below) of Vibrio spp. also possesses the PL subcomplexes [141], and spirochetes and firmicutes lack the L ring and PL ring, respectively [144], raising the question of whether there are still unknown functions of the $\mathrm{P}$ and $\mathrm{L}$ rings.

\subsection{The MS Ring is the Base of the Motor}

The MS ring, comprised solely of FliF, sits mainly in the periplasmic space but is anchored to the inner membrane via $\mathrm{N}$ - and C-terminal transmembrane helices [16,145]. FliF is a multidomain protein with two transmembrane domains, the ring-building motif domains (RBM) RBM1, RMB2, RBM3a, RBM3b, the $\beta$-collar domain, and C-terminal domain [146]. The C-terminal domain of FliF interacts with the N-terminus of the C-ring protein FliG [54,55], and the export gate complex resides within the MS ring [126,147]. A recent cryo-EM structural analysis of the MS ring answered the outstanding question of symmetry mismatch between the MS ring (25-fold) [106,108] and C ring (34-fold) $[106,148,149]$. The Lea group found that symmetry within the MS ring due to FliF folding creates an inner and outer ring. The export gate complex interacts with the 21/22-fold inner RBM domains, and the outer ring with 33/34-fold symmetry matches that of the $C$ ring [146]. The unique organization of FliF allows the MS ring to grasp the rotor and export gate, acting to stabilize the basal body. 


\subsection{The C Ring Acts as a Rotor Within the Cytosol}

The C ring, a notable structure located in the cytosol, is essential for flagellar rotation and assembly. The overall structure and shape are conserved, while the diameter of the $C$ ring can vary across species [113]. Cryo-EM and cryo-ET studies have shown that Salmonella and E. coli have C rings with $\sim 34$-fold symmetry [148,150], and bacterial species with larger motors, such as $\mathcal{\varepsilon}$-proteobacteria $[114,121]$ and spirochetes, possess $C$ rings with higher symmetry [116]. The increased resolution of cryo-ET has confirmed and expanded upon the initial observations of the $C$ ring diameter variation.

Insights into the $\mathrm{C}$ ring composition were inferred from the homologous non-flagellar type III secretion system (or injectosome, for review [7]) of Shigella [69,151]. Using sequence alignments, mass spectroscopy, and cryo-EM, McDowell et al. suggested that multimerization of a repeating heptamer [151] containing FliG, FliM, and FliN creates a C ring with a spiral base in lieu of the previously postulated hexamer $[152,153]$. This finding has further been substantiated by bioinformatics techniques, establishing an evolutionary precedent [154] and pseudo-atomic models built into cryo-ET maps $[120,128]$. FliG, comprised of three domains $\left(\mathrm{FliG}_{\mathrm{N}}, \mathrm{FliG}_{\mathrm{M}}\right.$, and $\mathrm{FliG}_{\mathrm{C}}$ ), occupies the $\mathrm{C}$ ring adjacent to the MS ring and stator, with FliG $_{N}$ interacting with FliF of the MS ring [54,55,155], and FliG interacting with MotA of the stator complex via charged residues [156-158]. FliM also contains three domains with similar nomenclature: FliM ${ }_{N}$ binds to CheY-P [67,159], FliM ${ }_{M}$ interacts with FliG $_{M}$ [160-162], and FliM ${ }_{C}$ forms a heterodimer with FliN [69,154]. FliN is a single-domain protein that dimerizes with FliM or itself $[163,164]$. Numerous crystal structures of the C-ring proteins provide critical information on protein-protein interactions (Table 1).

Some species have FliY, a protein with strong sequence homology to FliN and weak homology to FliM [163]. Typically, FliY replaces FliN, but in Leptospira and $\varepsilon$-proteobacteria, both FliY and FliN are expressed and necessary for flagellation $[63,165]$. The crystal structure of the FliN and FliY complex showed that these proteins form a heterodimer [63]. Co-expression and purification showed that Campylobacter jejuni FliY interacts with both FliN and FliM, but interestingly, FliN and FliM do not interact in $\varepsilon$-proteobacteria, Helicobacter pylori, or C. jejuni $[63,166,167]$. Recently, a detailed study of the $C$. jejuni $C$ ring composition established the distinct roles of FliY and FliN, as they appear to have evolved independently. The FliY and FliM interactions are important for stabilization of FliH, while FliN is necessary for stabilization of the $C$ ring, suggesting that the $C$ ring is composed of a FliG-FliM-FliN-FliY complex in C. jejuni [122]. Understanding C ring composition has proven very important in revealing the switching mechanism for controlling the rotational sense (discussed below).

\subsection{Torque is Generated by the Stator Through Ion Gradients}

The stator complex generates the torque required to rotate the $\mathrm{C}$ ring through a proton gradient, although some species use $\mathrm{Na}^{+}$ions [5,19,168,169]. Two membrane proteins, MotA and MotB, form the stator complex as the $\mathrm{H}^{+}$powered pump, while the $\mathrm{Na}^{+}$-driven pump assembles from PomA and PomB [170]. The complexity of the stator complex is two-fold: (1) the stator complex undergoes conformational changes to gain functionality, and (2) the stator complex pool is known to be dynamic [171], leading to variations in stator assembly [172-174]. The dynamic nature of the stator complex makes trapping it with the motor during purification difficult. For these reasons, much of our knowledge of the conformational changes during stator assembly has been accumulated through biochemical experiments, although structural information is starting to accumulate [175].

Initially, cryo-EM structures of PomA/PomB and MotA uncovered the shape and organization of a stator subunit but lacked vital information about stator stoichiometry and rotor-stator interactions $[109,171,176]$. Freeze-fractured micrographs $[177,178]$ and low-resolution cryo-ET [113,117,121,127,179,180] studies show the stator as a stud-like particle, with different species utilizing varying numbers of stators. Two recent high-resolution cryo-EM structures show that MotA:MotB and PomA:PomB exist in a 5:2 ratio [110,111]. Interestingly, one of these cryo-EM studies found very little conformational rearrangement of the stator complex during protonation in C. jejuni, using a protonation mimic mutant [110]. A cryo-ET study on B. burgdorferi greatly extended the 
resolution of the stator-C ring complex in situ, as the spirochete-specific collar of $B$. burgdorferi appears to stabilize the stator complexes around the C ring [116]. Mutations in MotB (D24N and D24E) result in non-motile and motile deficient spirochetes, respectively [116]. Furthermore, these mutations alter the number of stators assembled around the $C$ ring; from these variations in stator number, $C$ ring deformation increases with increased torque [116]. Cryo-ET partially resolved the elusive stator of Vibrio alginolyticus such that PomB appears to interact with MotX and MotY of the T ring, supporting the idea that the $\mathrm{H}$ and $\mathrm{T}$ ring help recruit the stators and allow for increased torque [181]. Evidently, bacteria have evolved sophisticated mechanisms to recruit stator complexes, perhaps to control torque necessary for different bacterial motility and behavior.

\subsection{A Conserved Mechanism for Flagellar Rotational Switching}

Bacteria move forward when the external flagella rotate in the CCW direction and tumble during CW rotation (Figure 1B) $[5,56,160,169,182]$. Notably, Vibrio spp. have a three-stroke swimming pattern, moving forward during CCW rotation, backward during CW rotation, and using a flicking motion upon CW-to-CCW rotation, analogous to the tumble (Figure 1C) [183]. Spirochete's periplasmic flagellar rotation is unique as forward movement occurs when flagella at one pole rotate CCW and the other CW, and tumbling occurs when flagella at both poles rotate in the CW direction (Figure 1D) [120,184-186]. The C ring controls the rotational sense in response to chemical attractions and repellents [12]. A chemotaxis system mediates the rotational sense via cooperative binding of phosphorylated CheY (CheY-P) to FliM, resulting in a CCW motor switching to the CW sense [67,159] (for review see [187]). A co-crystal structure of CheY-P bound to a truncation of FliM $\mathrm{N}_{\mathrm{N}}$ provided direct evidence of this interaction [72]. The presence of CheY at the $C$ ring has further been confirmed by two recent cryo-ET studies showing GFP-CheY at the outer periphery of the $\mathrm{C}$ ring. The first study used GFP-tagged CleD and CheY homolog in Caulobacter cresecentus [123], and the second used GFP-tagged CheY in B. burgdorferi [120].

The molecular mechanism of the $C$ ring rotational switching has been extensively studied. High-resolution microscopy of fluorescently tagged FliM and FliN provided evidence of a high turnover rate of FliM and a slower but significant turnover of FliN [188-191]. Fluorescent studies of FliM suggest $\sim 34$ copies are in CW rotating motors and $\sim 44$ copies in CCW rotating motors [189]. It is still unknown what makes FliM appear more stable during CCW rotation. Cryo-EM studies of purified motors do not show the large change suggested by high-resolution light microscopy studies [191] but suggest a slight diameter difference between CCW and CW motors [192]. Two recent cryo-ET studies in B. burgdorferi and $V$. alginolyticus revealed the $C$ ring conformational changes during rotational switching in situ $[120,128]$. These studies suggest that FliG-FliM-FliN stoichiometry remains consistent at 1:1:3 during switching, whereas there is a conformational change of the $C$ ring subunits that leads to the different presentation of FliG to the stator. The stator complexes were resolved in the B. burgdorferi motor structure, showing direct evidence for a difference in FliG-MotA interactions between the two rotational senses [120]. Using cryo-EM coupled with functional assays, Santiveri et al. suggest that MotA of the stator unit in C. jejuni rotates, specifically in a clockwise direction during protonation [110]. Together, these studies support a new model for the $C$ ring rotational switching, whereby the stator complex rotates in a CW manner, and the differences in the presentation of FliG to the stator complexes change the rotational sense of the C ring [110,111,120,128].

\subsection{The Export Apparatus Secretes Flagellar Proteins for Assembly}

The export apparatus is responsible for secreting proteins out of the cytoplasm and across the bacterial membranes to form a functional flagellum. Both proton motive force and ATP are utilized to unfold and translocate proteins across the cytoplasmic membrane. The export apparatus is composed of nine proteins: FlhA, FlhB, FliO, FliP, FliQ, FliR, FliH, FliI, and FliJ [24,25,118]. FlhA forms an ion channel [193-196] and has been shown biochemically and genetically to interact with multiple flagella-associated proteins [24,197-199]. FlhB, critical for substrate specificity, regulates the hook 
length and switching to flagellin secretion for filament assembly via an autocleavage event [200,201]. FliPQR forms the core complex, which is the channel that secretes the proteins [202]. The ATPase complex is formed by the ATPase (FliI), stalk protein (FliJ), and negative regulator (FliH) $[7,118]$.

The first hints of structural and spatial information about the export apparatus came from freeze fracture experiments, establishing the presence of a pore [177,203]. Multiple cryo-ET studies proposed the location of the export apparatus $[113,127,179,204]$; however, Chen et al. were the first to study the structural detail export apparatus in depth [113]. By comparing flagella from many species, they showed that the export apparatus is highly conserved in shape and location, with a dome feature below the MS ring, a torus, and a spherical structure. A FliI deletion in C. jejuni resulted in intact flagella missing the spherical density, solidifying the location of the export apparatus, specifically the ATPase portion [113]. A recent cryo-ET study showed that the ATPase portion of the export apparatus is connected to the $\mathrm{C}$ ring via interactions with $\mathrm{FliH}$ and likely rotates with the $\mathrm{C}$ ring [118]. FliH is a negative regulator of FliI, but exactly how the assembled FliH-FliI complex is regulated is still unknown; the crystal structure, while revealing an intriguing FliH dimer, did not bare the assembled ATPase complex structure [92]. Deletion of fliH in C. jejuni led to loss of FliI density but still allowed for flagella assembly, providing direct evidence that the ATPase is non-essential for flagella assembly, consistent with biochemical results [122].

A proton channel in FlhA has been shown to be critical for powering the export of flagellar proteins [205-208]. FlhA is the largest protein of the export gate and contains three cytoplasmic domains, CD1 with the FHIPEP motif, a linker domain Flh $A_{L}$ and a C-terminal domain Flh $A_{C}$, as well as two transmembrane regions $[193,209]$. The C-terminal domain, which interacts with the chaperones and export substrate, has been crystallized and studied extensively but lacks structural information for the remaining regions [84-86]. Inferences of the FlhA structure can be drawn from a cryo-ET study of the Salmonella non-flagellar T3SS, in which a seahorse-shaped structure was resolved for InvA, the homolog to FlhA [210]. The FliPQR-FlhB complex has recently been resolved in multiple cryo-EM studies, whereby purified FliPQR and FliPQR-FlhB of the export gate complex from Salmonella revealed an unexpected topology and orientation of the complex, with no canonical transmembrane regions but rather with a helical structure that sits at the base of the basal body, mainly inside the periplasm $[107,112,202]$. These studies also confirmed, using native mass spectrometry, that both the flagellar and non-flagellar export gates have a $\mathrm{P}_{5} \mathrm{Q}_{4} \mathrm{R}_{1}$ stoichiometry, and suggest that FlhB is important not only for the regulation of substrate export but also for the opening of the export gate, adding to the complexity [112,202]. A cryo-EM and cryo-ET study of the Salmonella non-flagellar T3SS showed that thinning of the membrane around the export apparatus allows the export gate to span the membrane by docking the high-resolution FliPQR structure [210]. The accumulation of information about the export apparatus points towards a complex highly conserved in sequence, structure, assembly, and function, although the molecular mechanism underlying protein secretion remains poorly understood [193].

\section{Specific Examples of Adaptation within the Bacterial Flagellum}

Since the first intact flagellar motor was visualized in Treponema primitia, a spirochete with periplasmic flagella, by cryo-ET [127,179], a thorough investigation of 11 bacterial species using cryo-ET by Chen et al. highlighted the vast differences among flagellar motors, leading to new insights into bacterial evolution [113]. The 'generic' model created by Chen et al., by averaging motors from 11 different species, suggests that the hook, rod, and L, P, and MS rings are highly conserved morphologically. The motors in Salmonella and E. coli are the best-known examples of the generic model (Figure 2). However, the flagellar motors in other species have evolved unique structural features, presumably to adapt to different environments [113]. In this section, we highlight evolutionary differences by specifically examining three subsets of bacteria: marine Vibrio, $\varepsilon$ - proteobacteria, and spirochetes. 


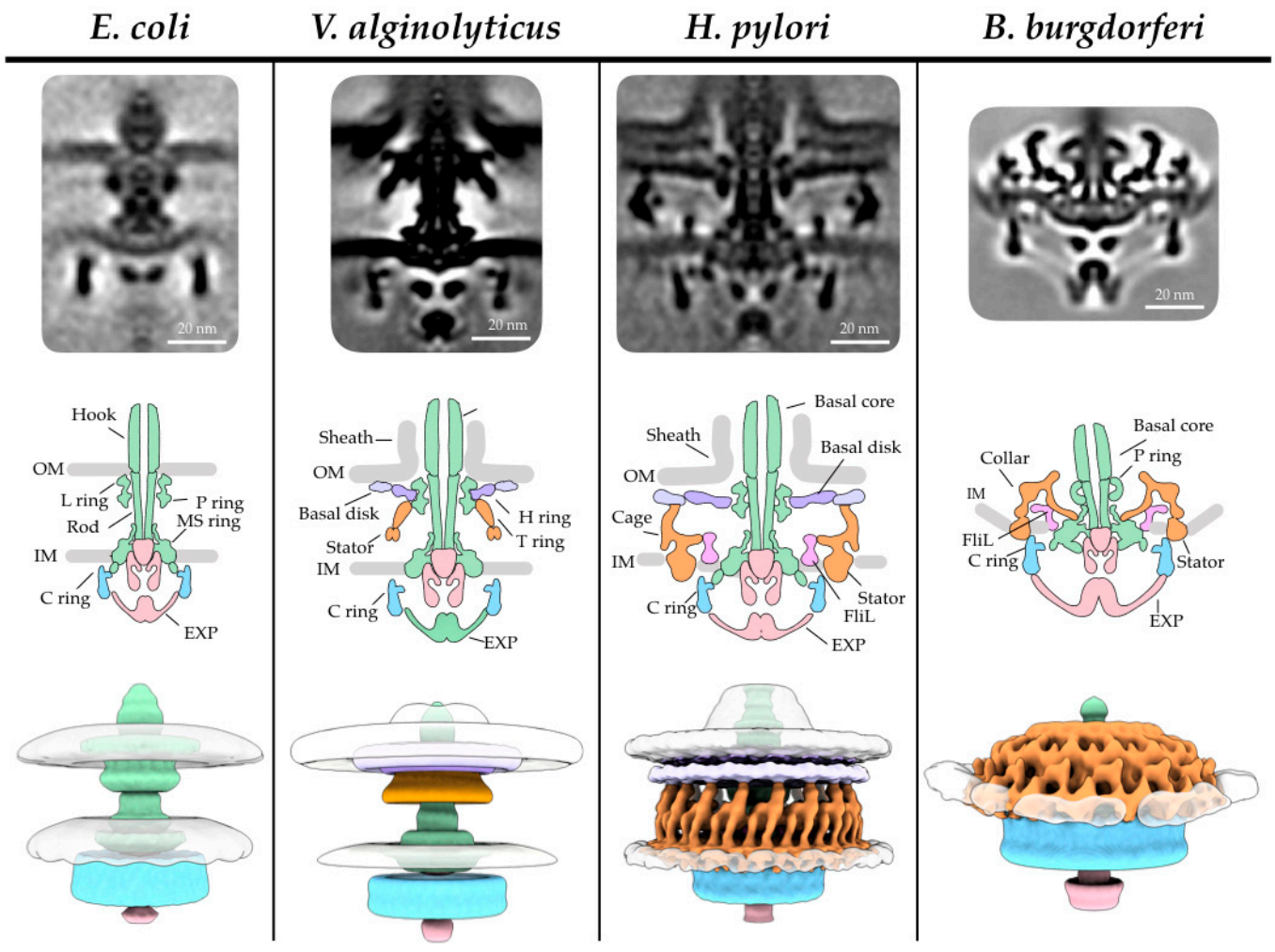

Figure 2. Intact flagellar motor structures reveal dramatic differences among species. Depicted for each species, from top to bottom, are the deposited class average of the motor, a cartoon model drawn from the class average, and a 3D reconstruction of the map. E. coli possess the simplest motor, resulting in a functional flagellum (EMDB 5311). Vibrio spp. have evolved additional rings that increase rotational speed. H. pylori (EMDB 8459), representing $\varepsilon$-proteobacteria, and B. burgdorferi (EMDB 0534), representing spirochetes, separately evolved structures that stabilize stators and increase rotor diameter, leading to greater torque generation.

\subsection{Vibrio Flagella Have Additional Rings in the Periplasm for Greater Torque Generation}

Vibrio species are marine bacteria that can cause gastroenteritis in humans via the consumption of contaminated water or seafood or via wound infections from swimming, with the well-known pathogen in this species being Vibrio cholera. The Vibrio single, polar, and sheathed flagellum has been studied in great detail biochemically (for example [211], for review of sheathed flagellum see [212]). Cryo-ET with STA revealed predominantly sheathed and, to a lesser extent, unsheathed flagella in wild-type V. alginolyticus (Figure 2). This allowed for the visualization of the membrane sheath and a novel O-ring structure [180]. A V. alginolyticus flh $G$ mutant that assembles multiple polar flagella [213] was used to gain resolution due to more particles per cell pole, and as expected, the sheathed flagellum appears very different from the unsheathed flagella of $V$. alginolyticus and E. coli. The diameter at the base of the flagellum was larger due to the membranous sheath, and the loss of the outer membrane-L ring fusion led to more mobility of the basal body. Additional density, named the $\mathrm{O}$ ring, was observed outside of the outer membrane, creating a $90^{\circ}$ kink in the outer membrane to form the sheath [180].

The Vibrio spp. motors also differ from E. coli and Salmonella, with the identification of the H (FlgT) and $\mathrm{T}$ (MotX and MotY) rings believed to have evolved to help the rotor spin faster, and stators that use $\mathrm{Na}^{+}$ion pumps in lieu of the more common $\mathrm{H}^{+}$ion pump composed of PomA/B [80,214,215]. The $\mathrm{T}$ ring was first identified via negative stain EM, whereby the Homma group showed that MotX and MotY form additional density associated with the LP rings and are required for PomA/B localization to the motor [214]. The $\mathrm{H}$ ring was later identified as FlgT and located above the $\mathrm{T}$ ring via negative stain EM [215]. A $V$. fischeri $\triangle m o t B$ mutant showed that the stator interacts with the 
T ring, allowing for the wider incorporation of the stator relative to Salmonella and thus increasing the torque generation $[80,83,121]$. Further use of the $\mathrm{V}$. alginolyticus flh $G$ mutation strain in the presence of $\Delta m o t Y$ or $\Delta m o t X$ suggests that the majority of the $T$ ring is composed of MotY, as the $\Delta m o t Y$ mutation resulted in the loss of the $\mathrm{T}$ ring density, and the $\Delta$ mot $X$ motors appeared relatively unchanged at low resolution. Importantly, the $V$. alginolyticus map revealed 13-fold symmetry of MotY, corresponding to the 13-fold symmetry of MotB in V. ficsheri [180]. Cryo-ET of $V$. ficheri $\Delta$ flgP [121] and V. alginolyticus $\Delta f l g O$ and $\Delta f l g T$ [216] mutants suggests that $\mathrm{FlgT}$, FlgO, and FlgP create the proximal, medial, and distal regions of the $\mathrm{H}$ ring, respectively. In the $V$. ficheri $\Delta f \lg P$, the stators did not assemble, and in the $V$. alginolyticus $\Delta f l g T$ the flagella were periplasmic. Taken together, these results suggest that the $\mathrm{H}$ and $\mathrm{T}$ rings, unique to $\mathrm{Na}^{+}$ion pump flagella, are required for proper flagellar assembly, stator association, and outer membrane penetration.

\subsection{The e-Proteobacteria Flagellum Cage Traps Additional Stators}

H. pylori is a well-known gastrointestinal pathogen that can cause stomach ulcers and cancer. H. pylori cells possess unipolar, sheathed flagella which allow the microbe to swim through the stomach mucosal lining and are essential for host infection. The function of the sheath still remains unknown. One possibility is that it protects the filament from the low $\mathrm{pH}$ of the stomach. Cryo-ET of the H. pylori motor revealed a very large motor $\sim 86 \mathrm{~nm}$ in diameter and $\sim 81 \mathrm{~nm}$ in height (Figure 2) [57]. The motor consists of the basal body core structures along with a novel periplasmic "cage-like" structure. The cage structure had 18-fold symmetry, with the densities below occupied by the stators [57]. This scaffold likely evolved to secure the 18 stators for the high torque generation needed to swim though the viscous environment of the human stomach mucous [57]. E. coli require only 11 stators in their flagella, as identified by total internal reflection fluorescence microscopy (TIRF) [171,174]. Cryo-ET revealed similar stator scaffolds in C. jejuni [121] (a gut pathogen that causes food poisoning) and Wolinella succinogenes [114] (a cattle rumen commensal) motors, albeit with 17-fold symmetry, suggesting that these microbes possess 17 stators. In C. jejuni, deletion mutants $\Delta f l g P, \Delta f l g Q, \Delta p f l A$, and $\triangle p f l B$, were analyzed by cryo-ET to address questions of motor assembly and the composition of the basal and medial disks. It was determined that FlgP creates the basal disk, FlgQ and PflA create the medial disk, and PflB creates the proximal disk [121]. There is a notable difference in C. jejuni, where the medial ring is parallel to the proximal ring and basal disk, contrasting with the perpendicular medial ring in H. pylori and W. succinogenes $[57,114]$. These structural difference most likely arise due to the FlgQ sequence diversity [114]. Chaban et al. postulate that the energy demand for such a continuously high stator load may be offset by the nutrient-rich habitat, as all three species are part of the gut flora in animals.

\subsection{The Periplasmic Flagella of Spirochetes Uses a Collar to Stabilize Stators}

Spirochetes are a unique family of bacteria with distinct morphology and motility. Some of them are known to cause diseases such as leptospirosis (Leptospira interrogans), syphilis (Treponema pallidum), and Lyme disease (B. burgdorferi). The flagella of spirochetes are unique due to the placement of the filament in the periplasmic space; this location has implications for the unique motility, host infection, and cell morphology of spirochetes [217] (for review [9]). From the first visualized in situ structures of the periplasmic flagellar motors in T. primitia [127] and B. burgdorferi $[117,204]$, it has been readily apparent that the periplasmic flagella have a larger $C$ ring, stator ring, and MS ring than those of Salmonella external flagella [12,218]. A spirochete-specific structure, also known as the collar, was identified [127]. The collar structure is approximately $71 \mathrm{~nm}$ in diameter and $24 \mathrm{~nm}$ in height, meaning the assembly is larger than the $C$ ring [204] (Figure 2).

The composition of the collar has recently been studied using B. burgdorferi as the model system $[9,217]$. To begin assigning B. burgdorferi proteins to the collar structure, all known flagellar proteins in B. burgdorferi were compared to those of externally flagellated genomes, and (BB0286) FlbB was identified as a potential hit. The $\triangle f l b B$ mutant cells are rod-shaped and non-motile. 
Visualization of the $\triangle f l b B$ motors by cryo-ET revealed that the collar did not assemble [219]. Furthermore, when $\triangle f l b B$ was complemented, $f l b B$ fused with green fluorescent protein (GFP) extra densities near the MS ring were resolved, suggesting that FlbB constitutes the base of the collar and that other proteins must be involved in collar formation [219]. To further identify collar proteins, the T. pallidum protein-protein interaction map was used to identify homologs with FlbB and interactors [220]. The protein of unknown function (BB0236) was identified and characterized via molecular and cryo-ET experiments. BB0236 was determined to directly interact with FlbB in pull-down assays. Like the FlbB deletion mutant, $\triangle b b 0236$ resulted in non-motile, rod-shaped bacteria. Cryo-ET showed that BB0236 is necessary for collar formation as well as for FliL and stator assembly, suggesting that BB0236 is a chaperone protein that aids in the formation of the collar, and that the collar provides support for the assembly of the stator and FliL [221]. The most recently identified collar protein was determined by a blast search of the peptidoglycan binding loop of MotB. The gene product of $b b 0326$ was renamed FlcA. The $\Delta f l c A$ mutant cells exhibited motility and morphology defects. Interestingly, cryo-ET demonstrated that the collar was assembled minus a region at the periphery, where FlcA resides. Density for FliL and FlbB was observed, suggesting that FlcA subsequently binds the collar. The stator was absent from the collar. FlcA was shown to interact with the stator protein MotB and the collar proteins FlbB and FliL, but not with BB0236 [222]. While the story of the spirochetal collar is still unfolding, cryo-ET combined with genetics has elegantly identified three proteins involved in collar assembly and shown the importance of the collar both for stabilization of the stator, by directly binding to MotB and the PG layer, and as a foundation for the stator assembly.

\section{Conclusions and Perspectives}

Bacterial flagella have evolved as highly versatile nanomachines that enable bacteria to navigate and survive diverse environments such as the mucous of the mammalian gut. Over the last decade, cryo-ET has enabled direct visualization of conservation and adaptation of the bacterial flagellum to niche environments. Cryo-EM and X-ray crystallography have led to near-atomic views of purified flagellar proteins and subcomplexes, such as the MS ring, $\mathrm{C}$ ring, and stator complexes. By combining these techniques, it is becoming feasible to establish nearly complete models of the flagellar motor, such as the one shown in Figure 3. High-resolution views of the intact flagellar motor not only significantly enhance our understanding of flagellar structure and assembly but also provide the basis to address fundamental questions about bacterial flagella: How does proton motive force drive the flagellar assembly and rotation? How does the flagellum switch its rotational direction? And how has the flagellum evolved as a highly diverse nanomachine? 
A
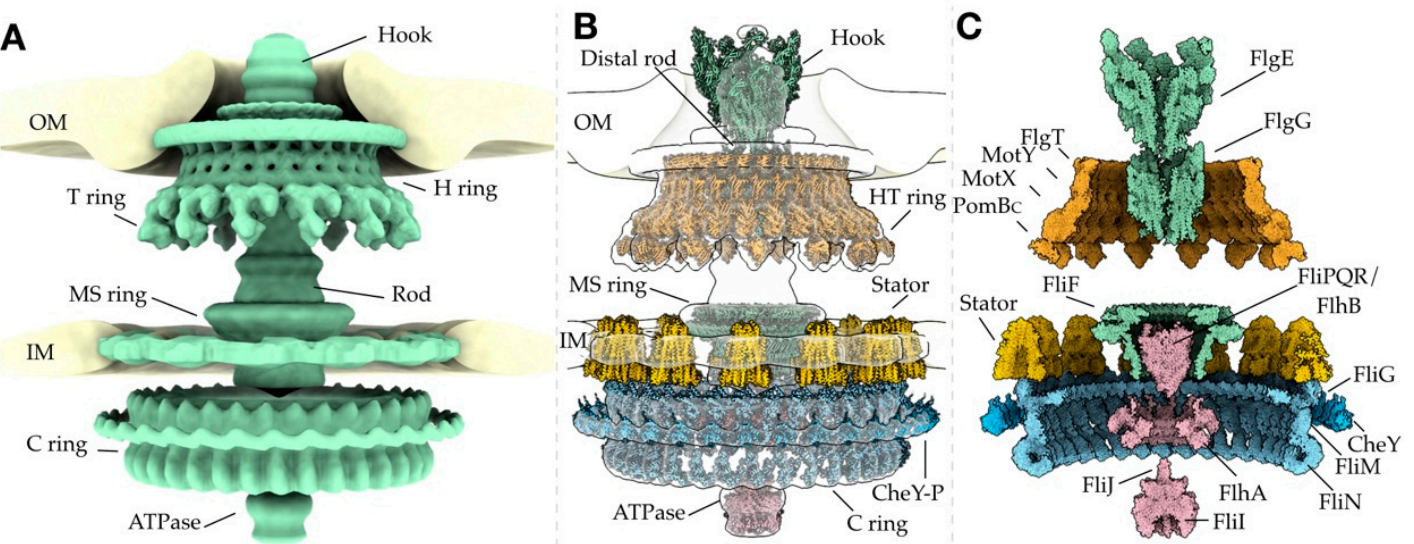

Figure 3. High-resolution cryo-EM and X-ray models placed in cryo-ET maps provide a basis for understanding flagellar assembly and function. (A). An assembled cryo-ET map of $z$ motor trapped in the CW rotation (EMDB 3155, 21837, and [143]), depicting the general shape of the molecular components that assemble into the intact motor. (B). High-resolution cryo-EM and X-ray structures of the flagellar components are placed in the cryo-ET map (white). The motor is sliced in half to show the inner and outer structures. (C). Available high-resolution structures are shown in full. The models used for this reconstruction are: FlgE (PDB 6KFK), FlgG (PDB 6JZR),

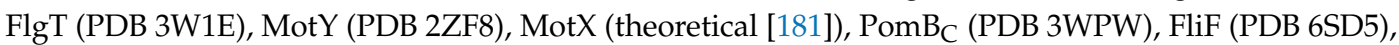
FliPQR-FlhB (PDB 6S3L), FliG (PDB 3HJL and 4FHR), CheY (PDB 1F4V), FliM (PDB 4FHR and 4YXB), FliN (PDB 4YXB and 1YAB), FlhA (PDB 6CH1), FliI (PDB 2DPY), Flij (PDB 3AJW), and stator (PDB 6YKM).

Author Contributions: B.L.C. wrote the draft, and B.L.C. and J.L. revised the manuscript. All authors have read and agreed to the published version of the manuscript.

Funding: The work in the Liu laboratory was supported in part by grants GM107629 and R01AI087946 from the National Institutes of Health.

Acknowledgments: We thank Jennifer Aronson for critical reading and suggestions.

Conflicts of Interest: The authors declare no conflict of interest.

\section{References}

1. Nakamura, S.; Minamino, T. Flagella-Driven Motility of Bacteria. Biomolecules 2019, 9, 279. [CrossRef]

2. Minamino, T.; Imada, K.; Namba, K. Molecular motors of the bacterial flagella. Curr. Opin. Struct. Biol. 2008, 18, 693-701. [CrossRef]

3. Pallen, M.J.; Matzke, N.J. From The Origin of Species to the origin of bacterial flagella. Nat. Rev. Genet. 2006, 4, 784-790. [CrossRef]

4. Terashima, H.; Kawamoto, A.; Morimoto, Y.V.; Imada, K.; Minamino, T. Structural differences in the bacterial flagellar motor among bacterial species. Biophys. Physicobiology 2017, 14, 191-198. [CrossRef]

5. Terashima, H.; Kojima, S.; Homma, M. Flagellar motility in bacteria structure and function of flagellar motor. Int. Rev. Cell. Mol. Biol. 2008, 270, 39-85. [CrossRef]

6. Zhao, X.; Norris, S.J.; Liu, J. Molecular Architecture of the Bacterial Flagellar Motor in Cells. Biochemistry 2014, 53, 4323-4333. [CrossRef]

7. Diepold, A.; Armitage, J.P. Type III secretion systems: The bacterial flagellum and the injectisome. Philos. Trans. R. Soc. B Biol. Sci. 2015, 370, 20150020. [CrossRef]

8. McCarter, L.L. Dual Flagellar Systems Enable Motility under Different Circumstances. J. Mol. Microbiol. Biotechnol. 2004, 7, 18-29. [CrossRef]

9. Chang, Y.; Liu, J. Architecture and Assembly of Periplasmic Flagellum. Microbiol. Spectr. 2019, 7, 10. [CrossRef]

10. Blair, D.F. Flagellar movement driven by proton translocation. FEBS Lett. 2003, 545, 86-95. [CrossRef] 
11. Francis, N.R.; Irikura, V.M.; Yamaguchi, S.; DeRosier, D.J.; Macnab, R.M. Localization of the Salmonella typhimurium flagellar switch protein FliG to the cytoplasmic M-ring face of the basal body. Proc. Natl. Acad. Sci. USA 1992, 89, 6304-6308. [CrossRef]

12. Francis, N.R.; Sosinsky, G.E.; Thomas, D.; DeRosier, D.J. Isolation, Characterization and Structure of Bacterial Flagellar Motors Containing the Switch Complex. J. Mol. Biol. 1994, 235, 1261-1270. [CrossRef]

13. Homma, M.; Ohnishi, K.; Iino, T.; Macnab, R.M. Identification of flagellar hook and basal body gene products (FlaFV, FlaFVI, FlaFVII and FlaFVIII) in Salmonella typhimurium. J. Bacteriol. 1987, 169, 3617-3624. [CrossRef]

14. Sato, K.; Homma, M. Multimeric Structure of PomA, a Component of the Na+-driven Polar Flagellar Motor ofVibrio alginolyticus. J. Biol. Chem. 2000, 275, 20223-20228. [CrossRef]

15. Sato, K.; Homma, M. Functional Reconstitution of the Na+-driven Polar Flagellar Motor Component ofVibrio alginolyticus. J. Biol. Chem. 2000, 275, 5718-5722. [CrossRef]

16. Ueno, T.; Oosawa, K.; Aizawa, S.-I. M ring, S ring and proximal rod of the flagellar basal body of Salmonella typhimurium are composed of subunits of a single protein, FliF. J. Mol. Biol. 1992, 227, 672-677. [CrossRef]

17. Asai, Y.; Kojima, S.; Kato, H.; Nishioka, N.; Kawagishi, I.; Homma, M. Putative channel components for the fast-rotating sodium-driven flagellar motor of a marine bacterium. J. Bacteriol. 1997, 179, 5104-5110. [CrossRef]

18. Braun, T.F.; Al-Mawsawi, L.Q.; Kojima, A.S.; Blair, D.F. Arrangement of Core Membrane Segments in the MotA/MotB Proton-Channel Complex ofEscherichia coli. Biochemistry 2004, 43, 35-45. [CrossRef]

19. Kojima, S.; Blair, D.F. The Bacterial Flagellar Motor: Structure and Function of a Complex Molecular Machine. Int. Rev. Cytol. 2004, 233, 93-134. [CrossRef]

20. Homma, M.; Kutsukake, K.; Hasebe, M.; Iino, T.; Macnab, R.M. FlgB, FlgC, FlgF and FlgG. A family of structurally related proteins in the flagellar basal body of Salmonella typhimurium. J. Mol. Biol. 1990, 211, 465-477. [CrossRef]

21. Kubori, T.; Shimamoto, N.; Yamaguchi, S.; Namba, K.; Aizawa, S.-I. Morphological pathway of flagellar assembly in Salmonella typhimurium. J. Mol. Biol. 1992, 226, 433-446. [CrossRef]

22. Minamino, T.; Yamaguchi, S.; Macnab, R.M. Interaction between FliE and FlgB, a Proximal Rod Component of the Flagellar Basal Body ofSalmonella. J. Bacteriol. 2000, 182, 3029-3036. [CrossRef]

23. Karlinsey, J.; Pease, A.J.; Winkler, M.E.; Bailey, J.L.; Hughes, K.T. The flk gene of Salmonella typhimurium couples flagellar P- and L-ring assembly to flagellar morphogenesis. J. Bacteriol. 1997, 179, 2389-2400. [CrossRef]

24. Fukumura, T.; Makino, F.; Dietsche, T.; Kinoshita, M.; Kato, T.; Wagner, S.; Namba, K.; Imada, K.; Minamino, T. Assembly and stoichiometry of the core structure of the bacterial flagellar type III export gate complex. PLoS Biol. 2017, 15, e2002281. [CrossRef]

25. Minamino, T.; Macnab, R.M. Components of the Salmonella Flagellar Export Apparatus and Classification of Export Substrates. J. Bacteriol. 1999, 181, 1388-1394. [CrossRef]

26. Minamino, T.; Macnab, R.M. Interactions among components of the Salmonella flagellar export apparatus and its substrates. Mol. Microbiol. 2000, 35, 1052-1064. [CrossRef]

27. Minamino, T. Protein export through the bacterial flagellar type III export pathway. Biochim. et Biophys. Acta (BBA)-Bioenerg. 2014, 1843, 1642-1648. [CrossRef]

28. Lucic, V.; Rigort, A.; Baumeister, W. Cryo-electron tomography: The challenge of doing structural biology in situ. J. Cell. Biol. 2013, 202, 407-419. [CrossRef]

29. Kim, M.I.; Lee, C.; Park, J.; Jeon, B.-Y.; Hong, M. Crystal structure of Bacillus cereus flagellin and structure-guided fusion-protein designs. Sci. Rep. 2018, 8, 5814. [CrossRef]

30. Samatey, F.A.; Imada, K.; Nagashima, S.; Vonderviszt, F.; Kumasaka, T.; Yamamoto, M.; Namba, K. Structure of the bacterial flagellar protofilament and implications for a switch for supercoiling. Nat. Cell Biol. 2001, 410, 331-337. [CrossRef]

31. Maruyama, Y.; Momma, M.; Mikami, B.; Hashimoto, W.; Murata, K. Crystal Structure of a Novel Bacterial Cell-Surface Flagellin Binding to a Polysaccharide. Biochemistry 2008, 47, 1393-1402. [CrossRef]

32. Nithichanon, A.; Rinchai, D.; Gori, A.; Lassaux, P.; Peri, C.; Conchillio-Solé, O.; Ferrer-Navarro, M.; Gourlay, L.J.; Nardini, M.; Vila, J.; et al. Sequence- and Structure-Based Immunoreactive Epitope Discovery for Burkholderia pseudomallei Flagellin. PLoS Neglected Trop. Dis. 2015, 9, e0003917. [CrossRef]

33. Song, W.S.; Yoon, S.-I. Crystal structure of FliC flagellin from Pseudomonas aeruginosa and its implication in TLR5 binding and formation of the flagellar filament. Biochem. Biophys. Res. Commun. 2014, 444, 109-115. [CrossRef] 
34. Evdokimov, A.G.; Phan, J.; Tropea, J.E.; Routzahn, K.M.; Peters, H.K.; Pokross, M.; Waugh, D.S. Similar modes of polypeptide recognition by export chaperones in flagellar biosynthesis and type III secretion. Nat. Struct. Mol. Biol. 2003, 10, 789-793. [CrossRef]

35. Lee, C.; Kim, M.I.; Park, J.; Jeon, B.-Y.; Yoon, S.-I.; Hong, M. Crystal structure of the flagellar chaperone FliS from Bacillus cereus and an invariant proline critical for FliS dimerization and flagellin recognition. Biochem. Biophys. Res. Commun. 2017, 487, 381-387. [CrossRef]

36. Lam, W.W.L.; Woo, E.J.; Kotaka, M.; Tam, W.K.; Leung, Y.C.; Ling, T.K.W.; Au, S.W.N. Molecular interaction of flagellar export chaperone FliS and cochaperone HP1076 in Helicobacter pylori. FASEB J. 2010, 24, 4020-4032. [CrossRef]

37. Horstmann, J.A.; Lunelli, M.; Cazzola, H.; Heidemann, J.; Kühne, C.; Steffen, P.; Szefs, S.; Rossi, C.; Lokareddy, R.K.; Wang, C.; et al. Methylation of Salmonella Typhimurium flagella promotes bacterial adhesion and host cell invasion. Nat. Commun. 2020, 11, 1-11. [CrossRef]

38. Gibson, K.H.; Trajtenberg, F.; Wunder, E.A.; Brady, M.R.; San Martin, F.; Mechaly, A.; Shang, Z.; Liu, J.; Picardeau, M.; Ko, A.; et al. An asymmetric sheath controls flagellar supercoiling and motility in the leptospira spirochete. eLife 2020, 9. [CrossRef]

39. Altegoer, F.; Mukherjee, S.; Steinchen, W.; Bedrunka, P.; Linne, U.; Kearns, D.B.; Bange, G. FliS/flagellin/FliW heterotrimer couples type III secretion and flagellin homeostasis. Sci. Rep. 2018, 8, 11552. [CrossRef]

40. Skorupka, K.; Han, S.K.; Nam, H.-J.; Kim, S.; Faham, S. Protein design by fusion: Implications for protein structure prediction and evolution. Acta Crystallogr. Sect. D Biol. Crystallogr. 2013, 69, 2451-2460. [CrossRef]

41. Kekez, I.; Cendron, L.; Stojanović, M.; Zanotti, G.; Matković-Čalogović, D. Structure and Stability of FlgD from the Pathogenic 26695 Strain of Helicobacter pylori. Croat. Chem. Acta 2016, 89, 1-7. [CrossRef]

42. Pulić, I.; Cendron, L.; Salamina, M.; De Laureto, P.P.; Matković-Čalogović, D.; Zanotti, G. Crystal structure of truncated FlgD from the human pathogen Helicobacter pylori. J. Struct. Biol. 2016, 194, 147-155. [CrossRef]

43. Yoon, Y.-H.; Barker, C.S.; Bulieris, P.V.; Matsunami, H.; Samatey, F.A. Structural insights into bacterial flagellar hooks similarities and specificities. Sci. Rep. 2016, 6, 35552. [CrossRef]

44. LoConte, V.; Kekez, I.; Matković-Čalogović, D.; Zanotti, G. Structural characterization of FlgE2 protein from Helicobacter pylori hook. FEBS J. 2017, 284, 4328-4342. [CrossRef]

45. Samatey, F.A.; Matsunami, H.; Imada, K.; Nagashima, S.; Shaikh, T.R.; Thomas, D.R.; Chen, J.Z.; DeRosier, D.J.; Kitao, A.; Namba, K. Structure of the bacterial flagellar hook and implication for the molecular universal joint mechanism. Nat. Cell Biol. 2004, 431, 1062-1068. [CrossRef]

46. Lynch, M.J.; Miller, M.; James, M.; Zhang, S.; Zhang, K.; Li, C.; Charon, N.W.; Pollack, L. Structure and chemistry of lysinoalanine crosslinking in the spirochaete flagella hook. Nat. Chem. Biol. 2019, 15, 959-965. [CrossRef]

47. Bulieris, P.V.; Shaikh, N.H.; Freddolino, P.L.; Samatey, F.A. Structure of FlgK reveals the divergence of the bacterial Hook-Filament Junction of Campylobacter. Sci. Rep. 2017, 7, 15743. [CrossRef]

48. Hong, H.J.; Kim, T.H.; Song, W.S.; Ko, H.-J.; Lee, G.-S.; Kang, S.G.; Kim, P.-H.; Yoon, S.-I. Crystal structure of FlgL and its implications for flagellar assembly. Sci. Rep. 2018, 8, 1-11. [CrossRef]

49. Postel, S.; Deredge, D.; Bonsor, D.A.; Yu, X.; Diederichs, K.; Helmsing, S.; Vromen, A.; Friedler, A.; Hust, M.; Egelman, E.H.; et al. Bacterial flagellar capping proteins adopt diverse oligomeric states. eLife 2016, 5, e18857. [CrossRef]

50. Cho, S.Y.; Song, W.S.; Oh, H.-B.; Kim, H.-U.; Jung, H.S.; Yoon, S.-I. Structural analysis of the flagellar capping protein FliD from Helicobacter pylori. Biochem. Biophys. Res. Commun. 2019, 514, 98-104. [CrossRef]

51. Saijo-Hamano, Y.; Matsunami, H.; Namba, K.; Imada, K. Architecture of the Bacterial Flagellar Distal Rod and Hook of Salmonella. Biochemistry 2019, 9, 260. [CrossRef]

52. Zaloba, P.; Bailey-Elkin, B.A.; Derksen, M.; Mark, B.L. Structural and Biochemical Insights into the Peptidoglycan Hydrolase Domain of FlgJ from Salmonella typhimurium. PLoS ONE 2016, 11, e0149204. [CrossRef]

53. Matsunami, H.; Yoon, Y.-H.; Meshcheryakov, V.A.; Namba, K.; Samatey, F.A. Structural flexibility of the periplasmic protein, FlgA, regulates flagellar P-ring assembly in Salmonella enterica. Sci. Rep. 2016, 6, 27399. [CrossRef]

54. Xue, C.; Lam, K.H.; Zhang, H.; Sun, K.; Lee, S.H.; Chen, X.; Au, S.W.N. Crystal structure of the FliF-FliG complex from Helicobacter pylori yields insight into the assembly of the motor MS-C ring in the bacterial flagellum. J. Biol. Chem. 2018, 293, 2066-2078. [CrossRef] 
55. Lynch, M.J.; Levenson, R.; Kim, E.A.; Sircar, R.; Blair, D.F.; Dahlquist, F.W.; Crane, B.R. Co-Folding of a FliF-FliG Split Domain Forms the Basis of the MS:C Ring Interface within the Bacterial Flagellar Motor. Struct. 2017, 25, 317-328. [CrossRef]

56. Lee, L.K.; Ginsburg, M.A.; Crovace, C.; Donohoe, M.; Stock, D. Structure of the torque ring of the flagellar motor and the molecular basis for rotational switching. Nat. Cell Biol. 2010, 466, 996-1000. [CrossRef]

57. Qin, Z.; Lin, W.-T.; Zhu, S.; Franco, A.T.; Liu, J. Imaging the Motility and Chemotaxis Machineries in Helicobacter pylori by Cryo-Electron Tomography. J. Bacteriol. 2016, 199, e00695-16. [CrossRef]

58. Hou, Y.; Sun, W.; Zhang, C.; Wang, T.; Guo, X.; Wu, L.; Qin, L.; Liu, T. Meta-analysis of the correlation between Helicobacter pylori infection and autoimmune thyroid diseases. Oncotarget 2017, 8, 115691-115700. [CrossRef]

59. Li, T.H.; Qin, Y.; Sham, P.C.; Lau, K.; Chu, K.-M.; Leung, W.K. Alterations in Gastric Microbiota After H. Pylori Eradication and in Different Histological Stages of Gastric Carcinogenesis. Sci. Rep. 2017, 7, 44935. [CrossRef]

60. Liu, A.Q.; Xie, Z.; Chen, X.N.; Feng, J.; Chen, J.W.; Qin, F.J.; Ge, L.Y. Fas-associated factor 1 inhibits tumor growth by suppressing Helicobacter pylori-induced activation of NF-kappaB signaling in human gastric carcinoma. Oncotarget 2017, 8, 7999-8009. [CrossRef]

61. Lam, K.-H.; Lam, W.W.L.; Wong, J.Y.-K.; Chan, L.-C.; Kotaka, M.; Ling, T.K.-W.; Jin, D.-Y.; Ottemann, K.M.; $\mathrm{Au}$, S.W.N. Structural basis of FliG-FliM interaction inHelicobacter pylori. Mol. Microbiol. 2013, 88, 798-812. [CrossRef]

62. Park, S.-Y.; Lowder, B.; Bilwes, A.M.; Blair, D.F.; Pollack, L. Structure of FliM provides insight into assembly of the switch complex in the bacterial flagella motor. Proc. Natl. Acad. Sci. USA 2006, 103, 11886-11891. [CrossRef]

63. Lam, K.-H.; Xue, C.; Sun, K.; Zhang, H.; Lam, W.W.L.; Zhu, Z.; Ng, J.T.Y.; Sause, W.E.; Lertsethtakarn, P.; Lau, K.; et al. Three SpoA-domain proteins interact in the creation of the flagellar type III secretion system in Helicobacter pylori. J. Biol. Chem. 2018, 293, 13961-13973. [CrossRef]

64. Brown, P.N.; Mathews, M.A.A.; Joss, L.A.; Hill, C.P.; Blair, D.F. Crystal Structure of the Flagellar Rotor Protein FliN from Thermotoga maritima. J. Bacteriol. 2005, 187, 2890-2902. [CrossRef]

65. Sircar, R.; Greenswag, A.R.; Bilwes, A.M.; Gonzalez-Bonet, G.; Crane, B.R. Structure and Activity of the Flagellar Rotor Protein FliY. J. Biol. Chem. 2013, 288, 13493-13502. [CrossRef]

66. Sircar, R.; Borbat, P.P.; Lynch, M.J.; Bhatnagar, J.; Beyersdorf, M.S.; Halkides, C.J.; Freed, J.H.; Crane, B.R. Assembly States of FliM and FliG within the Flagellar Switch Complex. J. Mol. Biol. 2015, 427, 867-886. [CrossRef]

67. Vartanian, A.S.; Paz, A.; Fortgang, E.A.; Abramson, J.; Dahlquist, F.W. Structure of Flagellar Motor Proteins in Complex Allows for Insights into Motor Structure and Switching. J. Biol. Chem. 2012, 287, 35779-35783. [CrossRef]

68. Paul, K.; Gonzalez-Bonet, G.; Bilwes, A.M.; Crane, B.R.; Blair, D.F. Architecture of the flagellar rotor. EMBO J. 2011, 30, 2962-2971. [CrossRef]

69. Notti, R.Q.; Bhattacharya, S.; Lilic, M.; Stebbins, C.E. A common assembly module in injectisome and flagellar type III secretion sorting platforms. Nat. Commun. 2015, 6, 7125. [CrossRef]

70. Couturier, C.; Silve, S.; Morales, R.; Pessegue, B.; Llopart, S.; Nair, A.; Bauer, A.; Scheiper, B.; Pöverlein, C.; Ganzhorn, A.; et al. Nanomolar inhibitors of Mycobacterium tuberculosis glutamine synthetase 1: Synthesis, biological evaluation and X-ray crystallographic studies. Bioorganic Med. Chem. Lett. 2015, 25, 1455-1459. [CrossRef]

71. Zhang, H.; Lam, K.-H.; Lam, W.W.L.; Wong, S.Y.Y.; Chan, V.S.F.; Au, S.W.N. A putative spermidine synthase interacts with flagellar switch protein FliM and regulates motility in Helicobacter pylori. Mol. Microbiol. 2017, 106, 690-703. [CrossRef]

72. Lee, S.Y.; Cho, H.; Pelton, J.G.; Yan, D.; Henderson, R.K.; King, D.S.; Huang, L.-S.; Kustu, S.; Berry, E.A.; Wemmer, D.E. Crystal structure of an activated response regulator bound to its target. Nat. Genet. 2001, 8, 52-56. [CrossRef]

73. Dyer, C.M.; Quillin, M.L.; Campos, A.; Lu, J.; McEvoy, M.M.; Hausrath, A.C.; Westbrook, E.M.; Matsumura, P.; Matthews, B.W.; Dahlquist, F.W. Structure of the Constitutively Active Double Mutant CheYD13K Y106W Alone and in Complex with a FliM Peptide. J. Mol. Biol. 2004, 342, 1325-1335. [CrossRef]

74. Dyer, C.M.; Dahlquist, F.W. Switched or Not?: The Structure of Unphosphorylated CheY Bound to the N Terminus of FliM. J. Bacteriol. 2006, 188, 7354-7363. [CrossRef] 
75. Ahn, D.-R.; Song, H.; Kim, J.; Lee, S.; Park, S. The crystal structure of an activated Thermotoga maritima CheY with N-terminal region of FliM. Int. J. Biol. Macromol. 2013, 54, 76-83. [CrossRef]

76. Biswas, M.; Dey, S.; Khamrui, S.; Sen, U.; Dasgupta, J. Conformational Barrier of CheY3 and Inability of CheY4 to Bind FliM Control the Flagellar Motor Action in Vibrio cholerae. PLoS ONE 2013, 8, e73923. [CrossRef]

77. Schuhmacher, J.S.; Rossmann, F.M.; Dempwolff, F.; Knauer, C.; Altegoer, F.; Steinchen, W.; Dörrich, A.K.; Klingl, A.; Stephan, M.; Linne, U.; et al. MinD-like ATPase FlhG effects location and number of bacterial flagella during C-ring assembly. Proc. Natl. Acad. Sci. USA 2015, 112, 3092-3097. [CrossRef]

78. Kojima, S.; Takao, M.; Almira, G.; Kawahara, I.; Sakuma, M.; Homma, M.; Kojima, C.; Imada, K. The Helix Rearrangement in the Periplasmic Domain of the Flagellar Stator B Subunit Activates Peptidoglycan Binding and Ion Influx. Struct. 2018, 26, 590-598.e5. [CrossRef]

79. Kojima, S.; Imada, K.; Sakuma, M.; Sudo, Y.; Kojima, C.; Minamino, T.; Homma, M.; Namba, K. Stator assembly and activation mechanism of the flagellar motor by the periplasmic region of MotB. Mol. Microbiol. 2009, 73, 710-718. [CrossRef]

80. Zhu, S.; Takao, M.; Li, N.; Sakuma, M.; Nishino, Y.; Homma, M.; Kojima, S.; Imada, K. Conformational change in the periplamic region of the flagellar stator coupled with the assembly around the rotor. Proc. Natl. Acad. Sci. USA 2014, 111, 13523-13528. [CrossRef]

81. Kojima, S.; Shinohara, A.; Terashima, H.; Yakushi, T.; Sakuma, M.; Homma, M.; Namba, K.; Imada, K. Insights into the stator assembly of the Vibrio flagellar motor from the crystal structure of MotY. Proc. Natl. Acad. Sci. USA 2008, 105, 7696-7701. [CrossRef]

82. Takekawa, N.; Isumi, M.; Terashima, H.; Zhu, S.; Nishino, Y.; Sakuma, M.; Kojima, S.; Homma, M.; Imada, K. Structure of Vibrio FliL, a New Stomatin-like Protein That Assists the Bacterial Flagellar Motor Function. mBio 2019, 10, e00292-19. [CrossRef]

83. Terashima, H.; Li, N.; Sakuma, M.; Koike, M.; Kojima, S.; Homma, M.; Imada, K. Insight into the assembly mechanism in the supramolecular rings of the sodium-driven Vibrio flagellar motor from the structure of FlgT. Proc. Natl. Acad. Sci. USA 2013, 110, 6133-6138. [CrossRef]

84. Bange, G.; Kümmerer, N.; Engel, C.; Bozkurt, G.; Wild, K.; Sinning, I. FlhA provides the adaptor for coordinated delivery of late flagella building blocks to the type III secretion system. Proc. Natl. Acad. Sci. USA 2010, 107, 11295-11300. [CrossRef]

85. Xing, Q.; Shi, K.; Portaliou, A.; Rossi, P.; Economou, A.; Kalodimos, C.G. Structures of chaperone-substrate complexes docked onto the export gate in a type III secretion system. Nat. Commun. 2018, 9, 1-9. [CrossRef]

86. Inoue, Y.; Ogawa, Y.; Kinoshita, M.; Terahara, N.; Shimada, M.; Kodera, N.; Ando, T.; Namba, K.; Kitao, A.; Imada, K.; et al. Structural Insights into the Substrate Specificity Switch Mechanism of the Type III Protein Export Apparatus. Struct. 2019, 27, 965-976.e6. [CrossRef]

87. Meshcheryakov, V.A.; Kitao, A.; Matsunami, H.; Samatey, F.A. Inhibition of a type III secretion system by the deletion of a short loop in one of its membrane proteins. Acta Crystallogr. Sect. D Biol. Crystallogr. 2013, 69, 812-820. [CrossRef]

88. Bange, G.; Petzold, G.; Wild, K.; Parlitz, R.O.; Sinning, I. The crystal structure of the third signal-recognition particle GTPase FlhF reveals a homodimer with bound GTP. Proc. Natl. Acad. Sci. USA 2007, 104, 13621-13625. [CrossRef]

89. Imada, K.; Minamino, T.; Tahara, A.; Namba, K. Structural similarity between the flagellar type III ATPase FliI and F1-ATPase subunits. Proc. Natl. Acad. Sci. USA 2007, 104, 485-490. [CrossRef]

90. Ibuki, T.; Imada, K.; Minamino, T.; Kato, T.; Miyata, T.; Namba, K. Common architecture of the flagellar type III protein export apparatus and F- and V-type ATPases. Nat. Struct. Mol. Biol. 2011, 18, 277-282. [CrossRef]

91. Kinoshita, M.; Nakanishi, Y.; Furukawa, Y.; Namba, K.; Imada, K.; Minamino, T. Rearrangements of $\alpha$-helical structures of FlgN chaperone control the binding affinity for its cognate substrates during flagellar type III export. Mol. Microbiol. 2016, 101, 656-670. [CrossRef]

92. Imada, K.; Minamino, T.; Uchida, Y.; Kinoshita, M.; Namba, K. Insight into the flagella type III export revealed by the complex structure of the type III ATPase and its regulator. Proc. Natl. Acad. Sci. USA 2016, 113, 3633-3638. [CrossRef]

93. Galkin, V.E.; Yu, X.; Bielnicki, J.; Heuser, J.; Ewing, C.P.; Guerry, P.; Egelman, E.H. Divergence of Quaternary Structures Among Bacterial Flagellar Filaments. Science 2008, 320, 382-385. [CrossRef]

94. Yonekura, K.; Maki-Yonekura, S.; Namba, K. Complete atomic model of the bacterial flagellar filament by electron cryomicroscopy. Nat. Cell Biol. 2003, 424, 643-650. [CrossRef] 
95. Maki-Yonekura, S.; Yonekura, K.; Namba, K. Conformational change of flagellin for polymorphic supercoiling of the flagellar filament. Nat. Struct. Mol. Biol. 2010, 17, 417-422. [CrossRef]

96. Wang, F.; Burrage, A.M.; Postel, S.; Clark, R.E.; Orlova, A.; Sundberg, E.J.; Kearns, D.B.; Egelman, E.H. A structural model of flagellar filament switching across multiple bacterial species. Nat. Commun. 2017, 8, 960. [CrossRef]

97. Yamaguchi, T.; Toma, S.; Terahara, N.; Miyata, T.; Ashihara, M.; Minamino, T.; Namba, K.; Kato, T. Structural and Functional Comparison of Salmonella Flagellar Filaments Composed of FljB and FliC. Biochemistry 2020, 10, 246. [CrossRef]

98. Blum, T.B.; Filippidou, S.; Fatton, M.; Junier, P.; Abrahams, J.P. The wild-type flagellar filament of the Firmicute Kurthia at $2.8 \AA$ resolution in vivo. Sci. Rep. 2019, 9, 14948. [CrossRef]

99. Matsunami, H.; Barker, C.S.; Yoon, Y.-H.; Wolf, M.; Samatey, F.A. Complete structure of the bacterial flagellar hook reveals extensive set of stabilizing interactions. Nat. Commun. 2016, 7, 13425. [CrossRef]

100. Shaikh, T.R.; Thomas, D.R.; Chen, J.Z.; Samatey, F.A.; Matsunami, H.; Imada, K.; Namba, K.; DeRosier, D.J. A partial atomic structure for the flagellar hook of Salmonella typhimurium. Proc. Natl. Acad. Sci. USA 2005, 102, 1023-1028. [CrossRef]

101. Horváth, P.; Kato, T.; Miyata, T.; Namba, K. Structure of Salmonella Flagellar Hook Reveals Intermolecular Domain Interactions for the Universal Joint Function. Biochemistry 2019, 9, 462. [CrossRef]

102. Fujii, T.; Kato, T.; Namba, K. Specific Arrangement of $\alpha$-Helical Coiled Coils in the Core Domain of the Bacterial Flagellar Hook for the Universal Joint Function. Structure 2009, 17, 1485-1493. [CrossRef]

103. Shibata, S.; Matsunami, H.; Aizawa, S.-I.; Wolf, M. Torque transmission mechanism of the curved bacterial flagellar hook revealed by cryo-EM. Nat. Struct. Mol. Biol. 2019, 26, 941-945. [CrossRef]

104. Kato, T.; Makino, F.; Miyata, T.; Horváth, P.; Namba, K. Structure of the native supercoiled flagellar hook as a universal joint. Nat. Commun. 2019, 10, 5295-5298. [CrossRef]

105. Maki-Yonekura, S.; Yonekura, K.; Namba, K. Domain movements of HAP2 in the cap-filament complex formation and growth process of the bacterial flagellum. Proc. Natl. Acad. Sci. USA 2003, 100, 15528-15533. [CrossRef] [PubMed]

106. Thomas, D.R.; Francis, N.R.; Xu, C.; DeRosier, D.J. The Three-Dimensional Structure of the Flagellar Rotor from a Clockwise-Locked Mutant of Salmonella enterica Serovar Typhimurium. J. Bacteriol. 2006, 188, 7039-7048. [CrossRef]

107. Johnson, S.; Kuhlen, L.; Deme, J.C.; Abrusci, P.; Lea, S.M. The Structure of an Injectisome Export Gate Demonstrates Conservation of Architecture in the Core Export Gate between Flagellar and Virulence Type III Secretion Systems. mBio 2019, 10, e00818-19. [CrossRef]

108. Suzuki, H.; Yonekura, K.; Namba, K. Structure of the Rotor of the Bacterial Flagellar Motor Revealed by Electron Cryomicroscopy and Single-particle Image Analysis. J. Mol. Biol. 2004, 337, 105-113. [CrossRef] [PubMed]

109. Takekawa, N.; Terahara, N.; Kato, T.; Gohara, M.; Mayanagi, K.; Hijikata, A.; Onoue, Y.; Kojima, S.; Shirai, T.; Namba, K.; et al. The tetrameric MotA complex as the core of the flagellar motor stator from hyperthermophilic bacterium. Sci. Rep. 2016, 6, 31526. [CrossRef]

110. Santiveri, M.; Roa-Eguiara, A.; Kühne, C.; Wadhwa, N.; Berg, H.C.; Erhardt, M.; Taylor, N.M.I. Structure and Function of Stator Units of the Bacterial Flagellar Motor. SSRN Electron. J. 2020, 183, 244-257. [CrossRef]

111. Deme, J.C.; Johnson, S.; Vickery, O.; Muellbauer, A.; Monkhouse, H.; Griffiths, T.; James, R.H.; Berks, B.C.; Coulton, J.W.; Stansfeld, P.J.; et al. Structures of the stator complex that drives rotation of the bacterial flagellum. Nat. Microbiol. 2020, 1-12. [CrossRef]

112. Kuhlen, L.; Johnson, S.; Zeitler, A.; Bäurle, S.; Deme, J.C.; Caesar, J.J.E.; Debo, R.; Fisher, J.; Wagner, S.; Lea, S.M. The substrate specificity switch FlhB assembles onto the export gate to regulate type three secretion. Nat. Commun. 2020, 11, 1296. [CrossRef] [PubMed]

113. Chen, S.; Beeby, M.; Murphy, G.E.; Leadbetter, J.R.; Hendrixson, D.R.; Briegel, A.; Li, Z.; Shi, J.; Tocheva, I.E.; Müller, A.; et al. Structural diversity of bacterial flagellar motors. EMBO J. 2011, 30, 2972-2981. [CrossRef] [PubMed]

114. Chaban, B.; Coleman, I.; Beeby, M. Evolution of higher torque in Campylobacter-type bacterial flagellar motors. Sci. Rep. 2018, 8, 1-11. [CrossRef] 
115. Zhang, K.; Qin, Z.; Chang, Y.; Liu, J.; Malkowski, M.G.; Shipa, S.; Li, L.; Qiu, W.; Zhang, J.; Li, C. Analysis of a flagellar filament cap mutant reveals that HtrA serine protease degrades unfolded flagellin protein in the periplasm of Borrelia burgdorferi. Mol. Microbiol. 2019, 111, 1652-1670. [CrossRef]

116. Chang, Y.; Moon, K.H.; Zhao, X.; Norris, S.J.; Motaleb, A.; Liu, J. Structural insights into flagellar stator-rotor interactions. eLife 2019, 8. [CrossRef] [PubMed]

117. Kudryashev, M.; Cyrklaff, M.; Wallich, R.; Baumeister, W.; Frischknecht, F. Distinct in situ structures of the Borrelia flagellar motor. J. Struct. Biol. 2010, 169, 54-61. [CrossRef]

118. Qin, Z.; Tu, J.; Lin, T.; Norris, S.J.; Li, C.; Motaleb, A.; Liu, J. Cryo-electron tomography of periplasmic flagella in Borrelia burgdorferi reveals a distinct cytoplasmic ATPase complex. PLoS Biol. 2018, 16, e3000050. [CrossRef]

119. Zhao, X.; Zhang, K.; Boquoi, T.; Hu, B.; Motaleb, A.; Miller, K.A.; James, M.E.; Charon, N.W.; Manson, M.D.; Norris, S.J.; et al. Cryoelectron tomography reveals the sequential assembly of bacterial flagella in Borrelia burgdorferi. Proc. Natl. Acad. Sci. USA 2013, 110, 14390-14395. [CrossRef]

120. Chang, Y.; Zhang, K.; Carroll, B.; Zhao, X.; Charon, N.W.; Norris, S.J.; Motaleb, A.; Li, C.; Liu, J. Molecular mechanism for rotational switching of the bacterial flagellar motor. Nat. Struct. Mol. Biol. 2020, 1-7. [CrossRef]

121. Beeby, M.; Ribardo, D.A.; Brennan, C.A.; Ruby, E.G.; Jensen, G.J.; Hendrixson, D.R. Diverse high-torque bacterial flagellar motors assemble wider stator rings using a conserved protein scaffold. Proc. Natl. Acad. Sci. USA 2016, 113, E1917-E1926. [CrossRef] [PubMed]

122. Henderson, L.D.; Matthews-Palmer, T.R.S.; Gulbronson, C.J.; Ribardo, D.A.; Beeby, M.; Hendrixson, D.R. Diversification of Campylobacter jejuni Flagellar C-Ring Composition Impacts Its Structure and Function in Motility, Flagellar Assembly, and Cellular Processes. mBio 2020, 11. [CrossRef]

123. Rossmann, F.M.; Hug, I.; Sangermani, M.; Jenal, U.; Beeby, M. In situ structure of the Caulobacter crescentus flagellar motor and visualization of binding of a CheY-homolog. Mol. Microbiol. 2020, 114, 443-453. [CrossRef]

124. Kaplan, M.; Ghosal, D.; Subramanian, P.; Oikonomou, C.M.; Kjaer, A.; Pirbadian, S.; Ortega, D.R.; Briegel, A.; El-Naggar, M.Y.; Jensen, G.J. The presence and absence of periplasmic rings in bacterial flagellar motors correlates with stator type. eLife 2019, 8. [CrossRef] [PubMed]

125. Ferreira, J.L.; Gao, F.Z.; Rossmann, F.M.; Nans, A.; Brenzinger, S.; Hosseini, R.; Wilson, A.; Briegel, A.; Thormann, K.M.; Rosenthal, P.B.; et al. gamma-proteobacteria eject their polar flagella under nutrient depletion, retaining flagellar motor relic structures. PLoS Biol. 2019, 17, e3000165. [CrossRef] [PubMed]

126. Kawamoto, A.; Morimoto, Y.V.; Miyata, T.; Minamino, T.; Hughes, K.T.; Kato, T.; Namba, K. Common and distinct structural features of Salmonella injectisome and flagellar basal body. Sci. Rep. 2013, 3, 3369. [CrossRef]

127. Murphy, G.E.; Leadbetter, J.R.; Jensen, G.J. In situ structure of the complete Treponema primitia flagellar motor. Nat. Cell Biol. 2006, 442, 1062-1064. [CrossRef]

128. Carroll, B.; Nishikino, T.; Guo, W.; Zhu, S.; Kojima, S.; Homma, M.; Liu, J. The flagellar motor of Vibrio alginolyticus undergoes major structural remodeling during rotational switching. eLife 2020, 9. [CrossRef] [PubMed]

129. Imada, K. Bacterial flagellar axial structure and its construction. Biophys. Rev. 2017, 10, 559-570. [CrossRef]

130. Turner, L.; Ryu, W.S.; Berg, H.C. Real-Time Imaging of Fluorescent Flagellar Filaments. J. Bacteriol. 2000, 182, 2793-2801. [CrossRef]

131. Macnab, R.M.; Ornston, M.K. Normal-to-curly flagellar transitions and their role in bacterial tumbling. Stabilization of an alternative quaternary structure by mechanical force. J. Mol. Biol. 1977, 112, 1-30. [CrossRef]

132. Macnab, R.M.; Koshland, D.E. The Gradient-Sensing Mechanism in Bacterial Chemotaxis. Proc. Natl. Acad. Sci. USA 1972, 69, 2509-2512. [CrossRef]

133. Berg, H.C.; Anderson, R.A. Bacteria Swim by Rotating their Flagellar Filaments. Nat. Cell Biol. 1973, 245, 380-382. [CrossRef] [PubMed]

134. Calladine, C.R. Construction of bacterial flagella. Nat. Cell Biol. 1975, 255, 121-124. [CrossRef] [PubMed]

135. Chevance, F.F.; Takahashi, N.; Karlinsey, J.E.; Gnerer, J.; Hirano, T.; Samudrala, R.; Aizawa, S.-I.; Hughes, K.T. The mechanism of outer membrane penetration by the eubacterial flagellum and implications for spirochete evolution. Genes Dev. 2007, 21, 2326-2335. [CrossRef] [PubMed]

136. Jones, C.J.; Macnab, R.M.; Okino, H.; Aizawa, S.-I. Stoichiometric analysis of the flagellar hook-(basal-body) complex of Salmonella typhimurium. J. Mol. Biol. 1990, 212, 377-387. [CrossRef] 
137. Müller, V.; Jones, C.J.; Kawagishi, I.; Aizawa, S.; Macnab, R.M. Characterization of the fliE genes of Escherichia coli and Salmonella typhimurium and identification of the FliE protein as a component of the flagellar hook-basal body complex. J. Bacteriol. 1992, 174, 2298-2304. [CrossRef]

138. Osorio-Valeriano, M.; De La Mora, J.; Camarena, L.; Dreyfus, G. Biochemical Characterization of the Flagellar Rod Components of Rhodobacter sphaeroides: Properties and Interactions. J. Bacteriol. 2015, 198, 544-552. [CrossRef]

139. Fujii, T.; Kato, T.; Hiraoka, K.D.; Miyata, T.; Minamino, T.; Chevance, F.F.V.; Hughes, K.T.; Namba, K. Identical folds used for distinct mechanical functions of the bacterial flagellar rod and hook. Nat. Commun. 2017, 8, 14276. [CrossRef]

140. Cohen, E.J.; Hughes, K.T. Rod-to-Hook Transition for Extracellular Flagellum Assembly Is Catalyzed by the L-Ring-Dependent Rod Scaffold Removal. J. Bacteriol. 2014, 196, 2387-2395. [CrossRef]

141. Kaplan, M.; Sweredoski, M.J.; Rodrigues, J.P.G.L.M.; Tocheva, E.I.; Chang, Y.-W.; Ortega, D.R.; Beeby, M.; Jensen, G.J. Bacterial flagellar motor PL-ring disassembly subcomplexes are widespread and ancient. Proc. Natl. Acad. Sci. USA 2020, 117, 8941-8947. [CrossRef]

142. Kaplan, M.; Subramanian, P.; Ghosal, D.; Oikonomou, C.M.; Pirbadian, S.; Starwalt-Lee, R.; Mageswaran, S.K.; Ortega, D.R.; Gralnick, J.A.; El-Naggar, M.Y.; et al. In situ imaging of the bacterial flagellar motor disassembly and assembly processes. EMBO J. 2019, 38, e100957. [CrossRef] [PubMed]

143. Zhu, S.; Schniederberend, M.; Zhitnitsky, D.; Jain, R.; Galán, J.E.; Kazmierczak, B.I.; Liu, J. In Situ Structures of Polar and Lateral Flagella Revealed by Cryo-Electron Tomography. J. Bacteriol. 2019, 201. [CrossRef]

144. Liu, R.; Ochman, H. Stepwise formation of the bacterial flagellar system. Proc. Natl. Acad. Sci. USA 2007, 104, 7116-7121. [CrossRef] [PubMed]

145. Ueno, T.; Oosawa, K.; Aizawa, S.-I. Domain Structures of the MS Ring Component Protein (FliF) of the Flagellar Basal Body of Salmonella typhimurium. J. Mol. Biol. 1994, 236, 546-555. [CrossRef] [PubMed]

146. Johnson, S.; Fong, Y.H.; Deme, J.C.; Furlong, E.J.; Kuhlen, L.; Lea, S.M. Symmetry mismatch in the MS-ring of the bacterial flagellar rotor explains the structural coordination of secretion and rotation. Nat. Microbiol. 2020, 5, 966-975. [CrossRef]

147. Wagner, S.; Königsmaier, L.; Lara-Tejero, M.; Lefebre, M.; Marlovits, T.C.; Galán, J.E. Organization and coordinated assembly of the type III secretion export apparatus. Proc. Natl. Acad. Sci. USA 2010, 107, 17745-17750. [CrossRef]

148. Thomas, D.R.; Morgan, D.G.; DeRosier, D.J. Rotational symmetry of the $\mathrm{C}$ ring and a mechanism for the flagellar rotary motor. Proc. Natl. Acad. Sci. USA 1999, 96, 10134-10139. [CrossRef]

149. Young, H.S.; Dang, H.; Lai, Y.; DeRosier, D.J.; Khan, S. Variable Symmetry in Salmonella typhimurium Flagellar Motors. Biophys. J. 2003, 84, 571-577. [CrossRef]

150. Zhao, R.; Amsler, C.D.; Matsumura, P.; Khan, S. FliG and FliM distribution in the Salmonella typhimurium cell and flagellar basal bodies. J. Bacteriol. 1996, 178, 258-265. [CrossRef]

151. McDowell, M.A.; Marcoux, J.; McVicker, G.; Johnson, S.; Fong, Y.H.; Stevens, R.; Bowman, L.A.H.; Degiacomi, M.T.; Yan, J.; Wise, A.; et al. Characterisation ofShigella Spa33 andThermotoga FliM/N reveals a new model for C-ring assembly in T3SS. Mol. Microbiol. 2015, 99, 749-766. [CrossRef]

152. Sarkar, M.K.; Paul, K.; Blair, D.F. Subunit Organization and Reversal-associated Movements in the Flagellar Switch of Escherichia coli. J. Biol. Chem. 2009, 285, 675-684. [CrossRef] [PubMed]

153. Bai, F.; Branch, R.W.; Nicolau, D.V.; Pilizota, T.; Steel, B.C.; Maini, P.K.; Berry, R.M. Conformational Spread as a Mechanism for Cooperativity in the Bacterial Flagellar Switch. Science 2010, 327, 685-689. [CrossRef] [PubMed]

154. Dos Santos, R.N.; Khan, S.; Morcos, F. Characterization of C-ring component assembly in flagellar motors from amino acid coevolution. R. Soc. Open Sci. 2018, 5, 171854. [CrossRef] [PubMed]

155. Ogawa, R.; Abe-Yoshizumi, R.; Kishi, T.; Homma, M.; Kojima, S. Interaction of the C-Terminal Tail of FliF with FliG from the Na+-Driven Flagellar Motor of Vibrio alginolyticus. J. Bacteriol. 2014, 197, 63-72. [CrossRef] [PubMed]

156. Lloyd, S.A.; Blair, D.F. Charged residues of the rotor protein FliG essential for torque generation in the flagellar motor of Escherichia coli. J. Mol. Biol. 1997, 266, 733-744. [CrossRef] [PubMed]

157. Yakushi, T.; Yang, J.; Fukuoka, H.; Homma, M.; Blair, D.F. Roles of Charged Residues of Rotor and Stator in Flagellar Rotation: Comparative Study using H+-Driven and $\mathrm{Na}+-$ Driven Motors in Escherichia coli. J. Bacteriol. 2006, 188, 1466-1472. [CrossRef] [PubMed] 
158. Takekawa, N.; Kojima, S.; Homma, M. Contribution of Many Charged Residues at the Stator-Rotor Interface of the Na+-Driven Flagellar Motor to Torque Generation in Vibrio alginolyticus. J. Bacteriol. 2014, 196, 1377-1385. [CrossRef]

159. Paul, K.; Brunstetter, D.; Titen, S.; Blair, D.F. A molecular mechanism of direction switching in the flagellar motor of Escherichia coli. Proc. Natl. Acad. Sci. USA 2011, 108, 17171-17176. [CrossRef]

160. Minamino, T.; Imada, K.; Kinoshita, M.; Nakamura, S.; Morimoto, Y.V.; Namba, K. Structural Insight into the Rotational Switching Mechanism of the Bacterial Flagellar Motor. PLoS Biol. 2011, 9, e1000616. [CrossRef]

161. Brown, P.N.; Hill, C.P.; Blair, D.F. Crystal structure of the middle and C-terminal domains of the flagellar rotor protein FliG. EMBO J. 2002, 21, 3225-3234. [CrossRef] [PubMed]

162. Brown, P.N.; Terrazas, M.; Paul, K.; Blair, D.F. Mutational Analysis of the Flagellar Protein FliG: Sites of Interaction with FliM and Implications for Organization of the Switch Complex. J. Bacteriol. 2006, 189, 305-312. [CrossRef] [PubMed]

163. Mathews, M.A.A.; Tang, H.L.; Blair, D.F. Domain Analysis of the FliM Protein ofEscherichia coli. J. Bacteriol. 1998, 180, 5580-5590. [CrossRef]

164. Paul, K.; Blair, D.F. Organization of FliN Subunits in the Flagellar Motor of Escherichia coli. J. Bacteriol. 2006, 188, 2502-2511. [CrossRef]

165. Lowenthal, A.C.; Hill, M.; Sycuro, L.K.; Mehmood, K.; Salama, N.R.; Ottemann, K.M. Functional Analysis of the Helicobacter pylori Flagellar Switch Proteins. J. Bacteriol. 2009, 191, 7147-7156. [CrossRef] [PubMed]

166. Häuser, R.; Ceol, A.; Rajagopala, S.V.; Mosca, R.; Siszler, G.; Wermke, N.; Sikorski, P.; Schwarz, F.; Schick, M.; Wuchty, S.; et al. A Second-generation Protein-Protein Interaction Network ofHelicobacter pylori. Mol. Cell. Proteom. 2014, 13, 1318-1329. [CrossRef] [PubMed]

167. Parrish, J.R.; Yu, J.; Liu, G.; Hines, J.A.; Chan, J.E.; Mangiola, B.A.; Zhang, H.; Pacifico, S.; Fotouhi, F.; DiRita, V.J.; et al. A proteome-wide protein interaction map for Campylobacter jejuni. Genome Biol. 2007, 8, 1-19. [CrossRef]

168. Li, N.; Kojima, S.; Homma, M. Sodium-driven motor of the polar flagellum in marine bacteria Vibrio. Genes Cells 2011, 16, 985-999. [CrossRef]

169. Berg, H.C. The Rotary Motor of Bacterial Flagella. Annu. Rev. Biochem. 2003, 72, 19-54. [CrossRef]

170. Kojima, S.; Blair, D.F. Solubilization and Purification of the MotA/MotB Complex ofEscherichia coli. Biochemistry 2004, 43, 26-34. [CrossRef]

171. Leake, M.C.; Chandler, J.H.; Wadhams, G.H.; Bai, F.; Berry, R.M.; Armitage, J.P. Stoichiometry and turnover in single, functioning membrane protein complexes. Nat. Cell Biol. 2006, 443, 355-358. [CrossRef]

172. Blair, D.F.; Berg, H.C. Restoration of torque in defective flagellar motors. Science 1988, 242, $1678-1681$. [CrossRef] [PubMed]

173. Block, S.M.; Berg, H.C. Successive incorporation of force-generating units in the bacterial rotary motor. Nat. Cell Biol. 1984, 309, 470-472. [CrossRef] [PubMed]

174. Reid, S.W.; Leake, M.C.; Chandler, J.H.; Lo, C.-J.; Armitage, J.P.; Berry, R.M. The maximum number of torque-generating units in the flagellar motor of Escherichia coli is at least 11. Proc. Natl. Acad. Sci. USA 2006, 103, 8066-8071. [CrossRef]

175. Baker, A.E.; O’Toole, G.A. Bacteria, Rev Your Engines: Stator Dynamics Regulate Flagellar Motility. J. Bacteriol. 2017, 199, e00088-17. [CrossRef] [PubMed]

176. Yonekura, K.; Maki-Yonekura, S.; Homma, M. Structure of the Flagellar Motor Protein Complex PomAB: Implications for the Torque-Generating Conformation. J. Bacteriol. 2011, 193, 3863-3870. [CrossRef]

177. Coulton, J.W.; Murray, R.G. Cell envelope associations of Aquaspirillum serpens flagella. J. Bacteriol. 1978, 136, 1037-1049. [CrossRef]

178. Khan, S.; Dapice, M.; Reese, T.S. Effects of mot gene expression on the structure of the flagellar motor. J. Mol. Biol. 1988, 202, 575-584. [CrossRef]

179. Liu, J.; Howell, J.K.; Bradley, S.D.; Zheng, Y.; Zhou, Z.H.; Norris, S.J. Cellular Architecture of Treponema pallidum: Novel Flagellum, Periplasmic Cone, and Cell Envelope as Revealed by Cryo Electron Tomography. J. Mol. Biol. 2010, 403, 546-561. [CrossRef]

180. Zhu, S.; Nishikino, T.; Hu, B.; Kojima, S.; Homma, M.; Liu, J. Molecular architecture of the sheathed polar flagellum in Vibrio alginolyticus. Proc. Natl. Acad. Sci. USA 2017, 114, 10966-10971. [CrossRef] 
181. Zhu, S.; Nishikino, T.; Takekawa, N.; Terashima, H.; Kojima, S.; Imada, K.; Homma, M.; Liu, J. In Situ Structure of the Vibrio Polar Flagellum Reveals a Distinct Outer Membrane Complex and Its Specific Interaction with the Stator. J. Bacteriol. 2019, 202. [CrossRef] [PubMed]

182. Chevance, F.F.V.; Hughes, K.T. Coordinating assembly of a bacterial macromolecular machine. Nat. Rev. Genet. 2008, 6, 455-465. [CrossRef]

183. Xie, L.; Altindal, T.; Chattopadhyay, S.; Wu, X.L. From the Cover: Bacterial flagellum as a propeller and as a rudder for efficient chemotaxis. Proc. Natl. Acad. Sci. USA 2011, 108, 2246-2251. [CrossRef]

184. Charon, N.W.; Cockburn, A.; Li, C.; Liu, J.; Miller, K.A.; Miller, M.R.; Motaleb, A.; Wolgemuth, C.W. The Unique Paradigm of Spirochete Motility and Chemotaxis. Annu. Rev. Microbiol. 2012, 66, 349-370. [CrossRef]

185. Charon, N.W.; Goldstein, S.F. Genetics of Motility and Chemotaxis of a Fascinating Group of Bacteria: The Spirochetes. Annu. Rev. Genet. 2002, 36, 47-73. [CrossRef] [PubMed]

186. Goldstein, S.F.; Buttle, K.F.; Charon, N.W. Structural analysis of the Leptospiraceae and Borrelia burgdorferi by high-voltage electron microscopy. J. Bacteriol. 1996, 178, 6539-6545. [CrossRef] [PubMed]

187. Minamino, T.; Kinoshita, M.; Namba, K. Directional Switching Mechanism of the Bacterial Flagellar Motor. Comput. Struct. Biotechnol. J. 2019, 17, 1075-1081. [CrossRef]

188. Branch, R.W.; Sayegh, M.N.; Shen, C.; Nathan, V.S.; Berg, H.C. Adaptive Remodelling by FliN in the Bacterial Rotary Motor. J. Mol. Biol. 2014, 426, 3314-3324. [CrossRef]

189. Lele, P.P.; Branch, R.W.; Nathan, V.S.J.; Berg, H.C. Mechanism for adaptive remodeling of the bacterial flagellar switch. Proc. Natl. Acad. Sci. USA 2012, 109, 20018-20022. [CrossRef]

190. Delalez, N.J.; Wadhams, G.H.; Rosser, G.; Xue, Q.; Brown, M.T.; Dobbie, I.M.; Berry, R.M.; Leake, M.C.; Armitage, J.P. Signal-dependent turnover of the bacterial flagellar switch protein FliM. Proc. Natl. Acad. Sci. USA 2010, 107, 11347-11351. [CrossRef]

191. Delalez, N.J.; Berry, R.M.; Armitage, J.P. Stoichiometry and Turnover of the Bacterial Flagellar Switch Protein FliN. mBio 2014, 5, e01216-14. [CrossRef] [PubMed]

192. Sakai, T.; Miyata, T.; Terahara, N.; Mori, K.; Inoue, Y.; Morimoto, Y.V.; Kato, T.; Namba, K.; Minamino, T. Novel Insights into Conformational Rearrangements of the Bacterial Flagellar Switch Complex. mBio 2019, 10, e00079-19. [CrossRef] [PubMed]

193. Erhardt, M.; Wheatley, P.; Kim, E.A.; Hirano, T.; Zhang, Y.; Sarkar, M.K.; Hughes, K.T.; Blair, D.F. Mechanism of type-III protein secretion: Regulation of FlhA conformation by a functionally critical charged-residue cluster. Mol. Microbiol. 2017, 104, 234-249. [CrossRef] [PubMed]

194. Minamino, T.; Morimoto, Y.V.; Hara, N.; Aldridge, P.D.; Namba, K. The Bacterial Flagellar Type III Export Gate Complex Is a Dual Fuel Engine That Can Use Both H+ and Na+ for Flagellar Protein Export. PLoS Pathog. 2016, 12, e1005495. [CrossRef]

195. Minamino, T.; Morimoto, Y.V.; Hara, N.; Namba, K. An energy transduction mechanism used in bacterial flagellar type III protein export. Nat. Commun. 2011, 2, 475. [CrossRef]

196. Morimoto, Y.V.; Kami-Ike, N.; Miyata, T.; Kawamoto, A.; Kato, T.; Namba, K.; Minamino, T. High-Resolution pH Imaging of Living Bacterial Cells To Detect Local pH Differences. mBio 2016, 7, e01911-16. [CrossRef]

197. Barker, C.S.; Samatey, F.A. Cross-Complementation Study of the Flagellar Type III Export Apparatus Membrane Protein FlhB. PLoS ONE 2012, 7, e44030. [CrossRef]

198. Hara, N.; Namba, K.; Minamino, T. Genetic Characterization of Conserved Charged Residues in the Bacterial Flagellar Type III Export Protein FlhA. PLoS ONE 2011, 6, e22417. [CrossRef]

199. Kihara, M.; Minamino, T.; Yamaguchi, S.; Macnab, R.M. Intergenic Suppression between the Flagellar MS Ring Protein FliF of Salmonella and FlhA, a Membrane Component of Its Export Apparatus. J. Bacteriol. 2001, 183, 1655-1662. [CrossRef]

200. Ferris, H.U.; Furukawa, Y.; Minamino, T.; Kroetz, M.B.; Kihara, M.; Namba, K.; Macnab, R.M. FlhB Regulates Ordered Export of Flagellar Components via Autocleavage Mechanism. J. Biol. Chem. 2005, 280, 41236-41242. [CrossRef]

201. Fraser, G.M.; Hirano, T.; Ferris, H.U.; Devgan, L.L.; Kihara, M.; Macnab, R.M. Substrate specificity of type III flagellar protein export in Salmonella is controlled by subdomain interactions in FlhB. Mol. Microbiol. 2003, 48, 1043-1057. [CrossRef] [PubMed] 
202. Kuhlen, L.; Abrusci, P.; Johnson, S.; Gault, J.; Deme, J.; Caesar, J.; Dietsche, T.; Mebrhatu, M.T.; Ganief, T.; Macek, B.; et al. Structure of the core of the type III secretion system export apparatus. Nat. Struct. Mol. Biol. 2018, 25, 583-590. [CrossRef] [PubMed]

203. Katayama, E.; Shiraishi, T.; Oosawa, K.; Baba, N.; Aizawa, S. Geometry of the flagellar motor in the cytoplasmic membrane of Salmonella typhimurium as determined by stereo-photogrammetry of quick-freeze deep-etch replica images. J. Mol. Biol. 1996, 255, 458-475. [CrossRef] [PubMed]

204. Liu, J.; Lin, T.; Botkin, D.J.; McCrum, E.; Winkler, H.; Norris, S.J. Intact Flagellar Motor of Borrelia burgdorferi Revealed by Cryo-Electron Tomography: Evidence for Stator Ring Curvature and Rotor/C-Ring Assembly Flexion. J. Bacteriol. 2009, 191, 5026-5036. [CrossRef] [PubMed]

205. Galperin, M.; Dibrov, P.A.; Glagolev, A.N. delta mu H+ is required for flagellar growth in Escherichia coli. FEBS Lett. 1982, 143, 319-322. [CrossRef]

206. Ewilharm, G.; Lehmann, V.; Krauss, K.; Lehnert, B.; Richter, S.; Ruckdeschel, K.; Heesemann, J.; Trülzsch, K. Yersinia enterocolitica Type III Secretion Depends on the Proton Motive Force but Not on the Flagellar Motor Components MotA and MotB. Infect. Immun. 2004, 72, 4004-4009. [CrossRef]

207. Paul, K.; Erhardt, M.; Hirano, T.; Blair, D.F.; Hughes, K.T. Energy source of flagellar type III secretion. Nat. Cell Biol. 2008, 451, 489-492. [CrossRef]

208. Minamino, T.; Namba, K. Distinct roles of the FliI ATPase and proton motive force in bacterial flagellar protein export. Nat. Cell Biol. 2008, 451, 485-488. [CrossRef]

209. Barker, C.S.; Inoue, T.; Meshcheryakova, I.V.; Kitanobo, S.; Samatey, F.A. Function of the conserved FHIPEP domain of the flagellar type III export apparatus, protein FlhA. Mol. Microbiol. 2016, 100, 278-288. [CrossRef]

210. Butan, C.; Lara-Tejero, M.; Li, W.; Liu, J.; Galán, J.E. High-resolution view of the type III secretion export apparatus in situ reveals membrane remodeling and a secretion pathway. Proc. Natl. Acad. Sci. USA 2019, 116, 24786-24795. [CrossRef]

211. Echazarreta, M.A.; Klose, K.E. Vibrio Flagellar Synthesis. Front. Cell. Infect. Microbiol. 2019, 9, 131. [CrossRef] [PubMed]

212. Chu, J.; Liu, J.; Hoover, T.R. Phylogenetic Distribution, Ultrastructure, and Function of Bacterial Flagellar Sheaths. Biomol. 2020, 10, 363. [CrossRef] [PubMed]

213. Kusumoto, A.; Shinohara, A.; Terashima, H.; Kojima, S.; Yakushi, T.; Homma, M. Collaboration of FlhF and FlhG to regulate polar-flagella number and localization in Vibrio alginolyticus. Microbiol. 2008, 154, 1390-1399. [CrossRef] [PubMed]

214. Terashima, H.; Fukuoka, H.; Yakushi, T.; Kojima, S.; Homma, M. The Vibrio motor proteins, MotX and MotY, are associated with the basal body of $\mathrm{Na}+$-driven flagella and required for stator formation. Mol. Microbiol. 2006, 62, 1170-1180. [CrossRef]

215. Terashima, H.; Koike, M.; Kojima, S.; Homma, M. The Flagellar Basal Body-Associated Protein FlgT Is Essential for a Novel Ring Structure in the Sodium-Driven Vibrio Motor. J. Bacteriol. 2010, 192, 5609-5615. [CrossRef]

216. Zhu, S.; Nishikino, T.; Kojima, S.; Homma, M.; Liu, J. The Vibrio H-Ring Facilitates the Outer Membrane Penetration of the Polar Sheathed Flagellum. J. Bacteriol. 2018, 200. [CrossRef]

217. Motaleb, A.; Corum, L.; Bono, J.L.; Elias, A.F.; Rosa, P.; Samuels, D.; Charon, N.W. Borrelia burgdorferi periplasmic flagella have both skeletal and motility functions. Proc. Natl. Acad. Sci. USA 2000, 97, 10899-10904. [CrossRef]

218. Sosinsky, G.E.; Francis, N.R.; Stallmeyer, M.; DeRosier, D.J. Substructure of the flagellar basal body of Salmonella typhimurium. J. Mol. Biol. 1992, 223, 171-184. [CrossRef]

219. Moon, K.H.; Zhao, X.; Manne, A.; Wang, J.; Yu, Z.; Liu, J.; Motaleb, A. Spirochetes flagellar collar protein FlbB has astounding effects in orientation of periplasmic flagella, bacterial shape, motility, and assembly of motors inBorrelia burgdorferi. Mol. Microbiol. 2016, 102, 336-348. [CrossRef]

220. Rajagopala, S.V.; Titz, B.; Goll, J.; Parrish, J.R.; Wohlbold, K.; McKevitt, M.T.; Palzkill, T.; Mori, H.; Jr, R.L.F.; Uetz, P. The protein network of bacterial motility. Mol. Syst. Biol. 2007, 3, 128. [CrossRef] 
221. Moon, K.H.; Zhao, X.; Xu, H.; Liu, J.; Motaleb, A. A tetratricopeptide repeat domain protein has profound effects on assembly of periplasmic flagella, morphology and motility of the lyme disease spirochete Borrelia burgdorferi. Mol. Microbiol. 2018, 110, 634-647. [CrossRef] [PubMed]

222. Xu, H.; He, J.; Liu, J.; Motaleb, A. BB0326 is responsible for the formation of periplasmic flagellar collar and assembly of the stator complex in Borrelia burgdorferi. Mol. Microbiol. 2019, 113, 418-429. [CrossRef]

Publisher's Note: MDPI stays neutral with regard to jurisdictional claims in published maps and institutional affiliations.

(C) 2020 by the authors. Licensee MDPI, Basel, Switzerland. This article is an open access article distributed under the terms and conditions of the Creative Commons Attribution (CC BY) license (http://creativecommons.org/licenses/by/4.0/). 